Review

\title{
Indicator Minerals, Pathfinder Elements, and Portable Analyti- cal Instruments in Mineral Exploration Studies
}

\author{
V. Balaram and S. S. Sawant
}

CSIR - National Geophysical Research Institute, Hyderabad - 500 007, India, balaram1951@yahoo.com

\begin{abstract}
Until recently, the classic approach to mineral exploration studies is to bring the field samples/drill cores collected during field studies to the laboratory followed by laborious analysis procedures to generate the analytical data. This is very expensive, time consuming and difficult for exploring vast areas. But rapid technological advances in field portable analytical instruments such as portable ultraviolet-visible and near-infrared spectrophotometers, gamma ray spectrometer, pXRF, pXRD, pLIBS, and $\mu$ Raman spectrometer have changed this scenario completely and increased their on-site applications in mineral exploration studies. These instruments are currently providing direct, rapid, on-site, real-time, non-destructive, cost-effective identification, and determination of target elements, indicator minerals and pathfinder elements in rock, soil, and sediment samples. These portable analytical instruments are currently helping to obtain accurate chemical and mineralogical information directly in field with minimal or no sample preparation, and providing decision-making support during field work as well as during drilling operations in several successful mineral exploration programs. In this article, the developments in these portable devices, and their contributions in the platinum group elements (PGE), rare earth elements (REE), gold, base metals, and lithium exploration studies both on land and on ocean bed have been summarized with examples.
\end{abstract}

Keywords: Portable instruments; indicator minerals; pathfinder elements; core scanners; pXRF; pXRD; pNIR-SWIR spectrometer; $\mu$ Raman spectrometer; LIBS; mineral exploration; on-site analysis

\section{Introduction}

The improvement in the living standards of a country is directly related to the country's ability to find, exploit, and manage its mineral resources. The exploration and mining industry requires new methods and tools to address the challenges of declining mineral reserves and increasing discovery costs. As the lucrative ore targets located in easily accessible metalliferous environments are depleting fast, the attention of exploration scientists is being shifted to the highly under-explored, and often problematic and inaccessible areas. Mineral exploration is a multidisciplinary team effort involving experts from different areas such as geology, geophysics, geochemistry, petrology, and engineering where geochemical techniques in particular have significantly contributed to the discoveries of several mineral deposits. Statistical data from China reveals that $71 \%$ of the total mineral deposits were discovered by geochemical methods during the period 1981-2000 (Figure 1) which demonstrates the power of geochemical exploration techniques. A large variety of approaches such as lithogeochemistry, stable and radiogenic isotopes, indicator minerals, hyperspectral scanning, biogeochemistry, hydrochemistry, and sediment geochemistry are utilized for understanding geochemical vectoring (Paulen et al. 2009; Chakraborty, 2020; Azmi et al. 2020; Balaram et al. 2022). The use of isotopic data in exploration geochemistry has still not become routine as getting such data is still difficult and expensive (Baumgartner et al. 2021). 


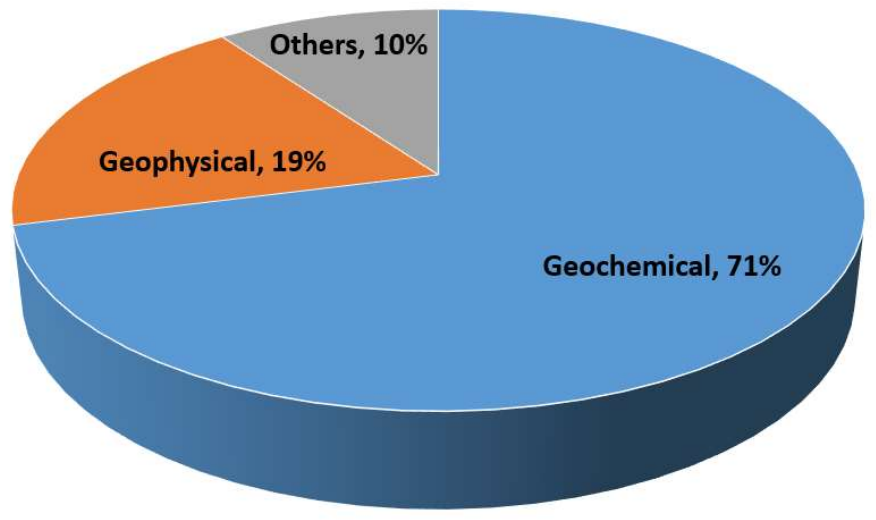

Figure 1. Geochemical methods have played an important role in the discoveries of 817 new mineral deposits in China during the period 1981-2000 (Modified after Xie et al. 2008).

In mineral exploration studies normally, geochemistry can help us with three aspects: i) lithology, particularly, mobile element geochemistry ii) alteration related to mineralogy, and iii) direct detection of mineralization with multi-element geochemistry. During the last half-a-century, the world has witnessed rapid advancements in analytical instruments for geochemical studies with the introduction of a series of new analytical techniques and technological advancements in allied areas (Balaram, 2021a). As a result, there have been significant developments in the accuracy and precision obtainable by even field portable analytical instruments such as portable X-ray fluorescence spectrometer ( $\mathrm{pXRF}$ ), portable $X$-ray diffractometer ( $p X R D)$, portable near infrared and short-wave infra-red spectrometers (pNIR-SWIR spectrometers), $\mu$ Raman spectrometer, portable laser induced breakdown spectrometer (pLIBS), core scanners, portable gamma spectrometers, used for mineral exploration studies. Although portable spark optical spectrometers are commercially available, its usefulness for geochemical analysis is not demonstrated yet. With the capability to generate rapid and in-situ high-quality data, these analytical techniques have been making the most significant contributions to relatively less expensive geochemical exploration studies leading to new discoveries. Though portable techniques such as pXRF existed much before, in recent times they became more versatile incorporating lightweight rechargeable batteries, global positioning systems (GPS), wireless computer technology, Bluetooth, remote control, operation capability and have become more accurate and helping the mineral exploration and mining industry in a big way. For example, most exploration geochemists use GPS to establish field/sample locations and these systems are now being integrated into all these field portable instruments. This article discusses the utility of the information on indicator minerals and pathfinder elements obtained by various portable instruments for identifying different ore deposits both on land and ocean floor. The basic principles on which these portable instruments work, their strengths and limitations, and evaluation of their performance using some practical examples are also presented.

\section{Indicator minerals}

Magmatic and hydrothermal minerals such as zircon, apatite, titanite and rutile are resistant to weathering and so end up in soil, till or stream sediments indicating their presence in bedrock of a specific type of mineralization, hydrothermal alteration or lithology, and these minerals are increasingly targeted in mineral exploration studies (McClenaghan, 2005). These are called indicator minerals which provide information of source magma chemistry, including crystallization temperatures, degree of fractionation, water content, and oxidation state. Indicator minerals have become important in exploration of gold, diamond, rare earth elements (REE), platinum group elements (PGE), base metals, lithium deposits in the past four decades and now. Currently suites of indicator minerals 
for different types of deposits have been identified by several studies (Table 1). For example, an indicator mineral survey in a glacial dispersal terrain containing highly elevated concentrations of sphalerite grains and minor galena helped to discover the prospect of base metal deposits hosted within the Cretaceous shale bedrock of northern Alberta, Canada (Paulen et al. 2009). Fayalite (Fe2SiO4), a reddish-brown to black mineral, the ironrich end-member of the olivine solid-solution series which can be found worldwide in igneous rock and abyssal rocks, is mainly mined for use as a gemstone and also for sandblasting. Fayalite crystals in the sediment of granite-like magma can contain large amounts of HREE (Brandt et al. 2020). Hence, fayalite helps to locate untapped REE deposits. Porter et al. (2020) described the use of the chemistry of detrital rutile as an indicator of mineralisations and identified some trace elements which uniquely distinguish rutile grains derived from mineralisations to those sourced from barren rocks. For example, rutile minerals sourced from $\mathrm{Au}$ deposits and enriched in $\mathrm{Sb}$, can be distinguished from rutile from pegmatites, which are enriched in $\mathrm{Nb}$, Ta and $\mathrm{Sn}$. Rutile minerals from barren rocks can be identified using W and Fe contents. Nzulu et al. (2021) in their gold exploration studies in Kubi Gold Project in the central region of Ghana with XRD studies, observed that the major pathfinding minerals for gold were quartz, magnetite and hematite. On the other hand, the contributions from minerals such as pyrite, arsenopyrite, iridosmine, scheelite, tetradymite, garnet and gypsum were found to be insignificant.

Table 1. Currently suites of indicator minerals for different types of deposits have been identified by several studies.

\begin{tabular}{|c|c|c|c|c|}
\hline $\begin{array}{l}\text { Deposits of } \\
\text { interest }\end{array}$ & $\begin{array}{l}\text { Type of } \\
\text { deposit }\end{array}$ & Main pathfinder minerals & $\begin{array}{l}\text { Main } \\
\text { pathfinder } \\
\text { elements }\end{array}$ & Reference \\
\hline Gold & & $\begin{array}{l}\text { Pyrite, chalco- pyrite, arsenopyrite, bismuthinite } \\
\text { magnetite, tellurides, tetrahedrite, pyrite, sphalerite, } \\
\text { muscovite, monazite, bastnäsite, quartz, scheelite, } \\
\text { wolframite, cassiterite }\end{array}$ & $\begin{array}{c}\mathrm{Fe}, \mathrm{Mn}, \mathrm{Cu}, \\
\mathrm{Co}, \mathrm{Ni}, \mathrm{Sb}, \\
\mathrm{Zn}, \mathrm{As}, \mathrm{Bi}, \mathrm{Te}, \\
\mathrm{Sn}, \mathrm{Se}, \mathrm{Tl}, \mathrm{Ag}, \\
\mathrm{Hg}, \mathrm{Pb}, \mathrm{Mo} \\
\text { and } \mathrm{W} .\end{array}$ & $\begin{array}{c}\text { Korshunova, } \\
\text { and Charykova, } \\
2019 \\
\text { Harder et al. } \\
2021 \\
\text { Nude et al. } \\
\text { (2021) } \\
\end{array}$ \\
\hline \multirow{4}{*}{ REE } & $\begin{array}{l}\text { Carbonatit } \\
\text { e rocks }\end{array}$ & $\begin{array}{l}\text { Bastnäsite group, ancylite, } \\
\text { monazite, (fluor)apatite, } \\
\text { pyrochlore, xenotime, florencite. }\end{array}$ & $\begin{array}{c}\mathrm{Na}, \mathrm{Mg}, \mathrm{Fe}, \mathrm{P}, \\
\mathrm{Ba}, \mathrm{F}, \mathrm{S}, \mathrm{Sr}, \mathrm{Ca}, \\
\mathrm{Nb}, \mathrm{Th}, \mathrm{U}, \mathrm{Zr}, \\
\mathrm{Cu}, \mathrm{Ta}, \mathrm{Ti}, \mathrm{V}, \\
\mathrm{Mn}, \mathrm{Pb} .\end{array}$ & \multirow{4}{*}{$\begin{array}{l}\text { Morgenstern et } \\
\text { al. } 2018\end{array}$} \\
\hline & $\begin{array}{l}\text { Igneous } \\
\text { rocks } \\
\text { (including } \\
\text { hydro- } \\
\text { thermal } \\
\text { upgrade) }\end{array}$ & $\begin{array}{c}\text { Bastnäsite group, aegirine, eudialyte, loparite, allanite, } \\
\text { monazite, fergusonite, zircon, xenotime, fluorapatite, } \\
\text { ancylite, gadolinite, euxenite, mosandrite. }\end{array}$ & $\begin{array}{c}\mathrm{Na}, \mathrm{K}, \mathrm{Fe}, \mathrm{Al}, \\
\mathrm{Zr}, \mathrm{Ti}, \mathrm{Nb}, \mathrm{Ta}, \\
\mathrm{Li}, \mathrm{F}, \mathrm{Cl}, \mathrm{Si}, \\
\mathrm{Th}, \mathrm{U}, \mathrm{P}, \mathrm{Cs}, \\
\mathrm{Rb}, \mathrm{Sn}, \mathrm{W}, \mathrm{Mo}, \\
\mathrm{Be}, \mathrm{Ga}, \mathrm{Hf} \\
\mathrm{Mn}, \mathrm{B} . \\
\end{array}$ & \\
\hline & $\begin{array}{l}\text { Placers } \\
\text { and } \\
\text { palaeoplac } \\
\text { ers }\end{array}$ & $\begin{array}{l}\text { Monazite, xenotime, } \\
\text { allanite, euxenite. }\end{array}$ & $\begin{array}{l}\mathrm{Ti}, \mathrm{Nb}, \mathrm{Zr}, \mathrm{Au} \text {, } \\
\mathrm{Sn}, \mathrm{Th}, \mathrm{U}, \mathrm{Pb} \\
\text { F. }\end{array}$ & \\
\hline & Laterites & $\begin{array}{c}\text { Monazite, apatite, } \\
\text { pyrochlore, crandallite } \\
\text { group, bastnäsite group, churchite, rhabdophane, } \\
\text { plumbogummite, zircon, }\end{array}$ & $\begin{array}{l}\mathrm{Fe}, \mathrm{Al}, \mathrm{Nb}, \mathrm{Zr} \\
\mathrm{Ti}, \mathrm{Sn}, \mathrm{Mn}, \mathrm{P} \\
\quad \text { low } \mathrm{Si}\end{array}$ & \\
\hline
\end{tabular}




\begin{tabular}{|c|c|c|c|c|}
\hline & & $\begin{array}{l}\text { florencite, xenotime, } \\
\text { cerianite. }\end{array}$ & $\begin{array}{l}\text { negative Ce } \\
\text { anomaly. }\end{array}$ & \\
\hline & Ion- & Clay minerals (mainly & High Si & \\
\hline & adsorption & kaolinite and halloysite). & (>75\%), low P. & \\
\hline & $\begin{array}{l}\text { Iron oxide- } \\
\text { associated } \\
\text { (including } \\
\text { IOCG) } \\
\text { deposits } \\
\end{array}$ & $\begin{array}{l}\text { Bastnäsite, synchysite, } \\
\text { monazite, xenotime, } \\
\text { florencite, britholite. }\end{array}$ & $\begin{array}{l}\mathrm{Fe}, \mathrm{Cu}, \mathrm{U}, \mathrm{Au} \\
\mathrm{Ag}, \mathrm{Ba}, \mathrm{F}, \mathrm{P}, \mathrm{S}\end{array}$ & \\
\hline & $\begin{array}{c}\text { Seafloor } \\
\text { deposits } \\
\text { such as } \\
\text { manganese } \\
\text { nodules, } \\
\text { ferromang } \\
\text { anese } \\
\text { crust, } \\
\text { phosphorit } \\
\text { e, etc. }\end{array}$ & $\begin{array}{c}\text { Vernadite, todorokite, Fe-oxyhydroxide, carbonate } \\
\text { fluorapatite, frrancolite }\end{array}$ & $\begin{array}{l}\mathrm{Mn}, \mathrm{Fe}, \mathrm{P}, \mathrm{Cu} \\
\mathrm{Ni}, \mathrm{Co} .\end{array}$ & \\
\hline Cu-Ni-PGE & & $\begin{array}{l}\text { pentlandite, chalcopyrite, pyrite, } \\
\text { millerite, PGM, chromite, Cr-diopside, } \\
\text { enstatite, olivine, Cr-andradite }\end{array}$ & $\begin{array}{l}\text { Ni, Cu, Pd, As, } \\
\text { Cr, Co, S, PGE }\end{array}$ & $\begin{array}{l}\text { Hattori and } \\
\text { Cameron, } 2004 \\
\text { Layton- } \\
\text { Matthews, } \\
\text { McClenaghan, } \\
\text { (2022) }\end{array}$ \\
\hline $\begin{array}{l}\text { Volcanogenic } \\
\text { massive sulphide } \\
\text { (VMS) deposits } \\
\text { (Cu, } \mathrm{Pb}, \mathrm{Zn}, \mathrm{Ag} \\
\mathrm{Au})\end{array}$ & & $\begin{array}{c}\text { Galena, sphalerite, chalcopyrite, } \\
\text { pyrrhotite, gold, pyrite, gahnite, } \\
\text { staurolite, cassiterite, spessartine, } \\
\text { sillimanite, andalusite, beudantite, } \\
\text { jarosite, barite, tourmaline, hogcomite, } \\
\text { nigerite }\end{array}$ & $\begin{array}{l}\mathrm{Cu}, \mathrm{Zn}, \mathrm{Pb}, \\
\mathrm{Ag}, \mathrm{Mo}, \mathrm{Sn}, \mathrm{Ba} \\
\mathrm{As}, \mathrm{Sb}, \mathrm{In}, \mathrm{Te} \\
\mathrm{Bi} \text {, and } \mathrm{Tl}\end{array}$ & $\begin{array}{l}\text { Hale, 1981; } \\
\text { Layton- } \\
\text { Matthews, } \\
\text { McClenaghan, } \\
\quad(2022) \\
\text { Gale, }(2003) \\
\end{array}$ \\
\hline $\begin{array}{l}\text { W-Mo-Bi, and Sn- } \\
\text { Zn-In deposits }\end{array}$ & & $\begin{array}{l}\text { Cassiterite, wolframite, } \underline{\text { molybdenite, }} \\
\text { topaz, chalcopyrite, galena, sphalerite, arsenopyrite, pyr } \\
\text { ite, loellingite, beudantite, anglesite, plumboferrite, } \\
\text { plumbogummite }\end{array}$ & $\begin{array}{c}\mathrm{Ag}, \mathrm{As}, \mathrm{Cd}, \\
{ }_{\mathrm{r}} \mathrm{Cu}, \mathrm{Pb}, \mathrm{Re}, \mathrm{Te}, \\
\mathrm{Tl}\end{array}$ & $\begin{array}{l}\text { McClenaghan et } \\
\text { al. } 2016\end{array}$ \\
\hline $\mathrm{Li}$ & & $\begin{array}{l}\text { Spodumene, petalite, amblygonite, quartz, K-feldspar, } \\
\text { albite, or montebrasite, lepidolite, zinnwaldite, } \\
\text { eucryptite, cassiterite, lithiophilite, holmquisite, } \\
\text { triphylite, quartz, muscovite, apatite, tourmaline } \\
\text { tantalite-columbite, and beryl. }\end{array}$ & $\begin{array}{l}\mathrm{K}, \mathrm{Ca}, \mathrm{Rb}, \mathrm{Sr} \\
\mathrm{Y}, \mathrm{Nb}, \mathrm{Sn}, \mathrm{Cs}, \\
\mathrm{Ta}, \mathrm{Sb}, \mathrm{W}, \mathrm{Bi} \\
\mathrm{As}, \mathrm{Ga}, \mathrm{Tl} \text {, and } \\
\quad \text { the REE }\end{array}$ & $\begin{array}{l}\text { Trueman and } \\
\text { Cerny, } 1982 \\
\text { Fabre et al. } 2021\end{array}$ \\
\hline $\begin{array}{l}\text { Kimberlite-hosted } \\
\text { diamonds }\end{array}$ & d & $\begin{array}{l}\text { Cr-pyrope, Cr-diopside, eclogitic garnet, } \\
\text { Mg-ilmenite, chromite, olivine, diamond }\end{array}$ & C & $\begin{array}{l}\text { Layton- } \\
\text { Matthews, } \\
\text { McClenaghan, } \\
\text { (2022) }\end{array}$ \\
\hline $\mathrm{U}$ & & $\begin{array}{c}\text { Uraninite (*pitchblende), thorianite, tourmaline, } \\
\text { sulphides, monazite, allanite, zircon, baddelyite, } \\
\text { niccolite, U-Th anatase, U-Th rutile, brannerite, } \\
\text { magnetite }\end{array}$ & $\begin{array}{c}\mathrm{Cu}, \mathrm{Ag}, \mathrm{As}, \\
\mathrm{Cr}, \mathrm{Pb}, \mathrm{Zn}, \mathrm{Ni} \text {, } \\
\mathrm{Co}, \mathrm{Re}, \mathrm{Be}, \mathrm{P}, \\
\mathrm{Mo}, \mathrm{Mn}, \mathrm{REE} \\
\text { and } \\
\text { radiogenic } \mathrm{Pb} \\
\text { isotopes }\end{array}$ & $\begin{array}{l}\text { Makvandi et al. } \\
2019 \\
\text { Joyce, } 2016 \\
\text { Cohen et al. } 1969\end{array}$ \\
\hline
\end{tabular}




\section{Pathfinder elements}

During exploration studies pathfinder elements together with indicator minerals (Table 1) provide a means to evaluate large areas for their mineral potential by eliminating likely barren areas from the areas under consideration. For example, mercury has been recognized as an indicator element for both noble, and base metal deposits (Plouffe, 2001). In addition, $\mathrm{As}, \mathrm{Mo}, \mathrm{Ag}, \mathrm{Sn}, \mathrm{Sb}, \mathrm{Te}, \mathrm{W}$ and $\mathrm{Bi}$ are also found to act as pathfinder elements for gold (Bayari et al. 2019). Though the use of As, Sb and Bi in stream sediments as pathfinder elements for base metal mineralization is well known, the influence of groundwater $\mathrm{pH}$ on the hydromorphic dispersion patterns of $\mathrm{As}, \mathrm{Sb}$ and $\mathrm{Bi}$, required to be considered during data interpretation (Hale, 1981). Somarin and Steinhage (2021) used Ni and Cu as pathfinder elements in the exploration study of PGE. These two elements were easily detected by $\mathrm{pXRF}$, and also showed positive correlations with the precious metals indicating that they can be used as pathfinders. Thus, the indicator minerals and pathfinder elements together provide a powerful and cost-effective means to evaluate large areas for their mineral potential. Sometimes the strongest signal came from the pathfinder element such as $\mathrm{Tl}$ and the target elements $\mathrm{Pb}$ and Ag gave only a weak signal (Johnsen et al. 2020). Nude et al. (2021) in their gold exploration studies in Wa-Lawra Belt, Northwest Ghana, using a multivariate statistical approach found out that Fe and Mn strongly associated with gold, and alongside $\mathrm{Pb}, \mathrm{Ag}$, As and $\mathrm{Cu}$, and these elements could be used as pathfinders for gold in the area, with ferruginous zones as targets. Kadel-Harder et al. (2020) in a study of identifying pathfinder elements for gold in the Cripple Creek alkaline igneous rockrelated, low-sulfidation epithermal gold telluride deposit in Colorado, US, found that Ag, $\mathrm{As}, \mathrm{Bi}, \mathrm{Te}$ and $\mathrm{W}$ are the best pathfinders, and tellurides, fluorite, quartz, carbonates, roscoelite, tennantite-tetrahedrite, pyrite, sphalerite, muscovite, monazite, bastnäsite and hübnerite are the indicator minerals to gold mineralization in low-grade disseminated ores.

\subsection{Element ratios}

Sometimes, the element ratios may be useful to evaluate litho-geochemical data, as a guide to different types of mineralization in rocks that either display alteration or have no recognizable alteration. For example, $\mathrm{K} / \mathrm{Rb}$ values of 4.8 , indicated highly fractionated bedrock and therefore a possible target for Li during lithium exploration studies (Steiner, 2019). These ratios can be used for the identification and assessment of granitic parent rock fertility with respect to the hosting potential of pegmatites. Lithium-bearing pegmatites are commonly referred to as lithium-cesium-tantalum (LCT) pegmatites due to the enrichment in the incompatible elements of $\mathrm{Li}, \mathrm{Cs}, \mathrm{Sn}, \mathrm{Rb}$, and Ta. Fertile granites exhibit elevated $\mathrm{Rb}, \mathrm{Cs}, \mathrm{Sn}$, and $\mathrm{Ta}$ as well as lower $\mathrm{K} / \mathrm{Rb}$ ratios than typical granites. Granites associated with mineralization commonly show a high $\mathrm{Rb} / \mathrm{Sr}$ ratio as a result of fractionation, and an increase in $\mathrm{Rb} / \mathrm{Sr}$ values has been reported from the periphery to the core of a porphyry copper deposit (Plimer and Elliott, 1979). Recently $\mathrm{Mg} / \mathrm{Fe}, \mathrm{Cr} / \mathrm{Al}$ and $\mathrm{Ca} / \mathrm{Na}$ ratios were used in order to understand the chemical and mineralogical expressions of large- and local-scale processes and to make detailed interpretations relevant for the genesis of mineralisations and metal distributions in chromite, orthopyroxene, and plagioclase in drill cores from Merensky Reef and UG-2 (Meima et al. 2022). Cao et al (2018) used the whole-rock $\mathrm{Ba}, \mathrm{V} / \mathrm{Ti}, \mathrm{Cu} / \mathrm{S}$ determined by $\mathrm{pXRF}$, and plagioclase, olivine, and clinopyroxene compositions measured by bench-top scanning electron microscope energy dispersive spectrometer (SEM-EDS) to explore PGE deposits.

\section{Portable techniques for mineral exploration studies}

As most of the surface and near surface mineral deposits have already been identified, current emphasis is to look for deposits in unexplored, under-explored areas, inaccessible regions, and also low-grade ore regions. After identifying surface expressions, it is necessary to take the help of the techniques that have the ability to locate deeply buried 
mineral deposits and drilling are required to conform the deposits later on. However, currently satellite images and aerial photographs are providing clear information on the geological structures and mineral alteration patterns by which potential areas for mineral exploration can be identified. In addition, both multispectral and hyperspectral sensors are playing a greater role in mineral exploration studies as they can cover larger areas. Several studies (e.g., Lindagato et al. 2018) have demonstrated that geostatistical analysis techniques to bedrock and stream sediments were successful in determining the background and threshold values and identifying $\mathrm{Au}$ and pathfinder anomalies. In addition, the number of faults and folds, in particular their junctions also help because those faults, fracture systems and permeability together enhance an easier and faster flow of hydrothermal fluids towards the surface, which results in the formation of geochemical anomalies. For example, critical aspects such as the geological setting, rock types, minerals, pathfinder element enrichments, the drainage patterns and the geophysical signatures must favor for identifying a deposit. Modern commercial miniature devices are commonly lighter than two kilograms and can be used in the field with ease (Balaram, 2018). Some of the most important portable analytical techniques used for the determination of indicator minerals and pathfinder elements will be discussed in the following in a more detailed manner.

\subsection{Portable short-wavelength infrared (SWIR) spectrometers}

Hyperspectral imagery (HSI) or reflective spectroscopy using short-wavelength infrared (SWIR) spectrometers which provide high spectral and spatial resolution data that may be used to map a broad range of mineral species associated with alteration and mineralization to help in increasing exploration throughputs. Infrared spectrometry is used to determine the mineral species, mineral composition and crystallinity of some common clay, carbonate and sulphate minerals present in rock samples. This technology measures the wavelengths of infrared light absorbed by the different chemical bonds to identify minerals present in a sample (van der, 2018). Each of the target minerals has a characteristic IR absorption pattern using which the mineral can be identified in addition to chemical variations and degree of crystallinity of minerals. These features can assist the exploration geologist in the interpretation of the style of mineral system under investigation, and also to understand mappable vectors toward zones that may host higher grades of the target commodity. HSI remote sensing technique is applied from airborne and spaceborne platforms directly to map a wide range of minerals in large areas. While satellite or airborne based HSI-platforms are advantageous for large-scale regional mapping, ground-based or drone-borne HSI can provide structural and mineralogical maps of outcrops with $\mathrm{mm}$ to $\mathrm{cm}$ precision. Earlier instruments covered visible (Vis) and near infrared (NIR) spectral ranges, but current instruments can cover the short-wave infra-red (SWIR) and thermal infra-red (TIR) ranges also. Figure 2 presents a portable UV-Vis-NIR (250-2500 nm range) spectrometer used for field geology. These field spectrometers with powerful sensors allow data capture over a wide spectral range, and provide information about the abundance and spatial location of ore and pathfinder minerals in drill-core, hand samples and outcrops with $\mathrm{mm}$ to $\mathrm{cm}$ precision in small selected areas. Recently Booysen et al. (2022) were able to identify lithium-bearing pegmatites at Uis, Namibia by hyperspectral imaging of mineralized outcrops. Later these findings were validated by drill-core data generated by XRD analysis and LIBS measurements. Many of the alteration minerals such as quartz, adularia, chlorite, illite, calcite, and pyrite can only be identified using mainly XRD or SWIR reflectance spectroscopy. Reflectance spectroscopy analyses are mostly made in the field using portable instruments directly on the rock sample that permits the collection of large datasets of closely spaced samples and require no sample preparation unlike XRD. XRD can detect a wider range of minerals, on the other hand SWIR spectroscopy is a very rapid, low-cost technique and permits the collection of large datasets of closely spaced samples which is not possible by XRD (Simpson et al. 2016). For example, VNIR-SWIR spectra of muscovite/white mica spectrum is shown in Figure 3. 


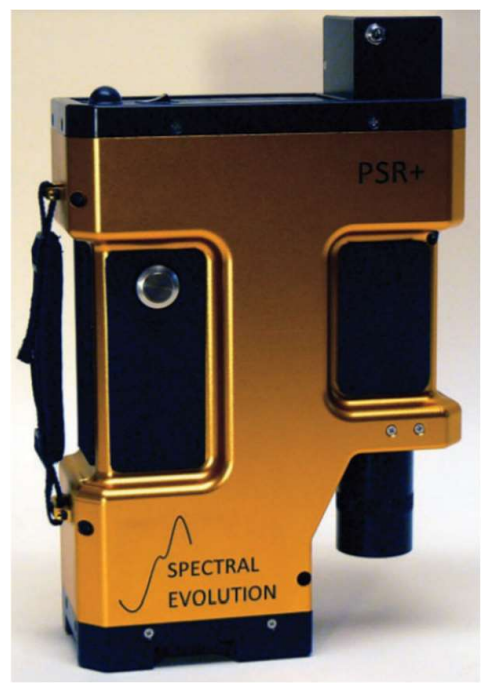

Figure 2. A portable UV-Vis-NIR (250-2500 nm range) spectroradiometer for field geology (Reproduced from Crocombe, 2018).

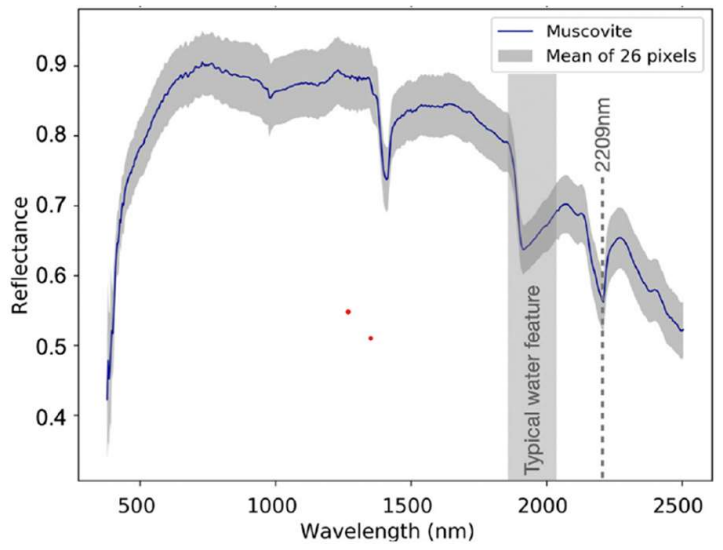

Figure 3. VNIR-SWIR spectra of muscovite/white mica spectrum (Reproduced from Booysen et al. 2022).

HIS can be used to identify various surficial rock forming minerals as well as rare earth elements (REE). Neodymium (Nd) has some of the most pronounced absorption features among the REE and therefore can be used as a key pathfinder element for total REE. Nd has characteristic absorption features in the visible to near-infrared (VNIR) range of the electromagnetic spectrum at $580 \mathrm{~nm}, 750 \mathrm{~nm}$, and $800 \mathrm{~nm}$. Booysen et al. (2020) carried out REE exploration studies using an innovative and non-invasive unmanned aerial vehicle (UAV)-based hyperspectral methodology for the first time, demonstrating the direct mapping of REE with lightweight hyperspectral UAV platforms. Recently, Barton et al (2021) used a drone- and tripod-based field hyperspectral imaging for large scale mineral mapping in and around the active Lisbon Valley copper mine demonstrating the utility of hyperspectral imaging as a technique for general mineral characterization in mining applications. Stuart et al. (2021) went a step further and introduced a low-cost smartphone-based hyperspectral imaging system that can convert a standard smartphone camera into a visible wavelength hyperspectral sensor, and obtained dataset of an obsidian flow banded ash tuff, clearly highlighting the individual flow bands with the key reflectance feature spectral curve for a sulphur at ca. $500 \mathrm{~nm}$. In the case of lithium exploration, two of the major pathfinder minerals for lithium are lepidolite and spodumene (Table 1). A sample can be identified as lepidolite with distinct features at $580 \mathrm{~nm}, 2190 \mathrm{~nm}$ 
and $2340 \mathrm{~nm}$. A spodumene sample could show absorption features at $550 \mathrm{~nm}, 1980 \mathrm{~nm}$, and $2320 \mathrm{~nm}$ by a NIR field spectrometer covering 350-2500 $\mathrm{nm}$ range. Soil spectroscopy by portable instruments also minimizes the number of soil samples collected for laboratory studies which also require extensive sample pre-treatment procedures such as drying and grinding. The near infrared spectroscopy can distinguish the crystallinity of single mineral (clay minerals, chlorite, serpentine, etc.), containing hydroxy silicate minerals (epidote, amphibole, etc.), sulfate minerals (alunite, pyrite potassium alum, gypsum, etc.), and carbonate minerals (calcite, dolomite, etc.) in the layered silicate. Liancun et al. (2017) used a portable near infrared spectrometer to acquire characteristic spectra of altered minerals, and to establish the relationship between altered minerals and ore-forming.

\subsection{Portable Fourier transformed infrared spectrometer (FTIR)}

In the pursuit of search for valuable minerals and to obtain insight into the distribution of mineral grades, yet another low cost and rapid technique called portable fourier transformed infrared spectrometer (FTIR) was developed which is based on the absorption of light from the spectrum of a light source. IR spectroscopy gets absorption of a monochromatic IR light at a time and draws the spectrum, whereas in FTIR, multi-chromatic (a beam from several frequencies of light) takes a summarized absorption of light and distributes it to create a spectrum using FTIR. Dispersion or Fourier transform is used for spectral analysis. FT-IR is a faster, more effective and non-destructive technique that provides information about the chemical composition, mineralogical and structural features of a geological sample. Near IR band (pNIR) or the middle IR band (pMIR) of the electromagnetic spectrum can be used to determine the presence of certain minerals by identifying features in a transmitted or reflected spectrum. Figure 4 presents a photo of a commercial portable FTIR spectrometer, and its schematic diagram. These instruments operate usually in diffuse reflectance, but attenuated total reflection (ATR) can also be used for spot surficial measurements for identifying a variety of minerals as well as organic compounds (Lemière and Uvarova, 2019). Near infrared (NIR), as well as hyperspectral visible to near-infrared (VNIR), have been considered as potential tools for ore sorting. Silicate, carbonate and hydroxide minerals are known to be active in the middle infrared (MIR) range and display a unique reflectance feature due to fundamental stretching and vibrational motions (Salisbury et al. 1986). FTIR is a rapid, non-destructive, and low-cost method which requires little sample preparation (samples are crushed and pelletized before measuring the reflectance spectra) or no sample preparation and the modal mineralogy data obtained often complement the elemental analysis by pXRF and LIBS, for target identification and delineation.

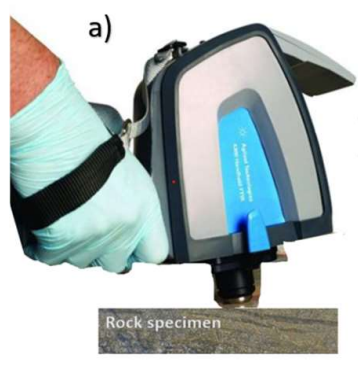

b)

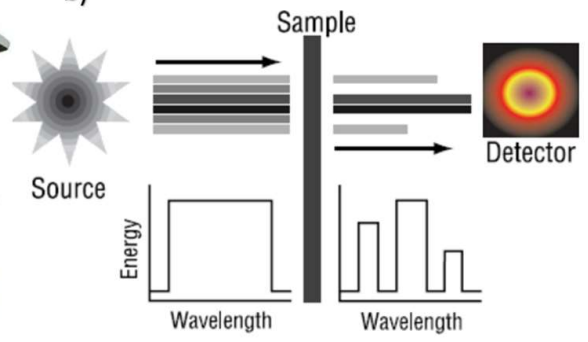

Figure 4. (a) Portable FTIR spectrometer, (b) a schematic diagram of a portable spectrometer (Modified after Kakavand and Adl-Zarrabi, 2015 [56]).

4.2.1. FTIR spectroscopy in copper mining and metallurgy 
Dehaine et al. (2022) used the portable FTIR spectroscopy to measure the mineralogy of drill core samples from the sediment-hosted Cu-deposits of the Democratic Republic of Congo. The type of mineral assemblages and gangue mineralogy will have a bearing on the extraction process (i.e., leaching vs. flotation) to be used for the extraction of $\mathrm{Cu}$ and Co. Comprehensive understanding of variation of ore mineralogy and texture in the deposit is essential in order to optimize resource efficiency and reduce technical risks and environmental impacts.

\subsection{Radiometric surveys}

Radiometric or gamma ray spectrometry surveys have been widely used in studies related to mineral exploration, geological mapping and environmental radiation monitoring. One of the most significant advances in uranium exploration has been the development of gamma ray spectrometric techniques beyond several other applications including geothermal exploration (Killeen, 1979; McCay et al. 2014). Using the natural radioactivity of certain elements/isotopes (e.g., 40K, 234Th, 238U), the concentrations of these elements can be determined by using hyperspectral remote sensing $\gamma$-ray spectrometry (e.g., Geiger counter), fluorimetry, and other geochemical techniques by drone, and handheld instruments for the generation of precise mapping of these radioactive elements in selected areas. The radiometric methods are capable of detecting these elements at the surface of the ground, in drill-holes, and even on outcrops. The common radioactive minerals are uraninite, monazite, thorianite, rubidium-rich feldspars in a granitic pegmatite, muscovite, sylvite in acid igneous rocks. The earliest detectors on logging tools were Geiger counters, but these have been replaced by crystal scintillation detectors in most modern tools. These techniques are especially valuable in the studies related to uranium exploration (Bharti et al. 2015). Maden and Akaryali (2015) used potassium as pathfinder element along with magnetic data to identify gold mineralizations zones associated with the $\mathrm{K}$ alteration in the eastern Pontide orogenic belt of the Alpine-Himalayan system. The deposit has a high level of altered rock surrounding the deposits which usually have a distinct radioelement signature useful for exploration studies. Portable gamma ray spectrometry surveys are particularly well suited to REE exploration studies as the ores of REE may contain trace to anomalous concentrations of radioactive elements, K, U and Th (Shives, 2015).

\section{4. $p X R F$}

Portable XRF ( $\mathrm{pXRF}$ ) is fast becoming an important toolkit for geochemical exploration studies. When a sample is bombarded with an X-ray beam with spot sizes of $0.5 \mathrm{~mm}$ to $2 \mathrm{~mm}$, electrons get displaced from the inner shell of an atom, and the vacancy from the inner shell then gets replaced with an electron from an outer shell. As this electron fills the vacancy of the inner shell, it releases energy in the form of a secondary X-ray fluorescence which is characteristic to each element. By measuring these characteristic radiations at a particular wavelength or energy, it is possible to determine the elements (both qualitative and quantitative) present in the sample. The detection and measurement of emitted $X$-rays is done in two different ways: (a) wavelength dispersive XRF (WD-XRF) employs a crystal, a kind of diffraction grating to disperse the spectrum according to X-ray wavelength - rather like a prism that splits visible light into the colors of the rainbow, and (b) energy dispersive XRF (ED-XRF) determines the energies of different X-rays in the spectrum directly. Portable XRF ( $\mathrm{pXRF}$ ) is a miniature version of ED-XRF. Schematic diagram showing the configuration of a typical hand-held XRF analyzer is presented in Figure 5. Portable XRF is simple to use, can easily be carried and operated using only one hand and can provide an onsite nondestructive chemical analysis of over 30 elements ranging in concentration from about $10 \mu \mathrm{g} / \mathrm{g}$ to $100 \%$, in less than a minute with detection limits ranging from $5-10 \mu \mathrm{g} / \mathrm{g}$ in the field (Table 2). Figure 6 depicts a spectrum of serpentinite and meta basaltic rocks obtained by portable XRF. Recent developments in microelectronics and advanced chips helped to drastically reduce the size of specialist components of 
sophisticated analytical instrumentations in general. (Potts and Webb, 1992; Yellepeddi and Thomas, 2006; Hall et al. 2015; Balaram, 2021a). The triboluminescent X-ray generation technology eliminated the high-voltage power supply, and has a profound impact on current day XRF technologies, enabling cost and size reductions at a scale not possible with conventional technology (Camara et al. 2008). These advancements made new generation pXRF instruments very powerful. Some important features include, rapid collection of data on a large number of samples and replicate analyses, acquisition of higher data density compatible with geostatistics, lower detection limits for several elements, most inter-element interferences are automatically corrected for different elements across the periodic table, and these instruments don't require laboratory environment for proper functioning. However, pXRF has limitations such as matrix interferences on the elements that can be measured, for example, the interferences from the REE on transition elements can affect the data which cannot be completely corrected (Gallhofer and Lottermoser, 2018).

Table 2. Limits of detection (LOD) for some important elements (in $\mu \mathrm{g} / \mathrm{g}$ ) across the periodic table by portable XRF (Durance et al. 2014).

\begin{tabular}{cccccccc}
\hline Element & pXRF LOD & Element & pXRF LOD & Element & pXRF LOD & Element & pXRF LOD \\
\hline $\mathrm{Ag}$ & $<10$ & $\mathrm{Cr}$ & $<10$ & $\mathrm{~Pb}$ & $<0.05$ & $\mathrm{Ti}$ & $<10$ \\
\hline $\mathrm{As}$ & $<5$ & $\mathrm{Cu}$ & $<10$ & $\mathrm{Rb}$ & $<5$ & $\mathrm{~V}$ & $<10$ \\
\hline $\mathrm{Au}$ & $<10$ & $\mathrm{Fe}$ & $<10$ & $\mathrm{~S}$ & $<200$ & $\mathrm{~W}$ & $<10$ \\
\hline $\mathrm{Ca}$ & $<50$ & $\mathrm{~K}$ & $<50$ & $\mathrm{Sn}$ & $<20$ & $\mathrm{Y}$ & $<5$ \\
\hline $\mathrm{Cl}$ & $<200$ & $\mathrm{Mn}$ & $<10$ & $\mathrm{Sr}$ & $<5$ & $\mathrm{Zn}$ & $\mathrm{Zr}$ \\
\hline $\mathrm{Co}$ & $<10$ & $\mathrm{Mo}$ & $<5$ & $\mathrm{Th}$ & $<5$ & $<5$ \\
\hline
\end{tabular}

Use of pXRF in exploration for specialty metals such as gold, REE, PGE, Nb, Zr, and Ta has achieved varying degrees of success. Among a number of advantages of $p X R F$, the possibility to perform on-site measurements with minimum sample preparation is important. Usually, pressed pellets of samples prepared in the field are used for analysis. However, when sample preparation is not possible, multiple scans with multiple data points are necessary to produce some potential averages. pXRF is capable of analyzing elements from $\mathrm{Mg}$ to $\mathrm{U}$.

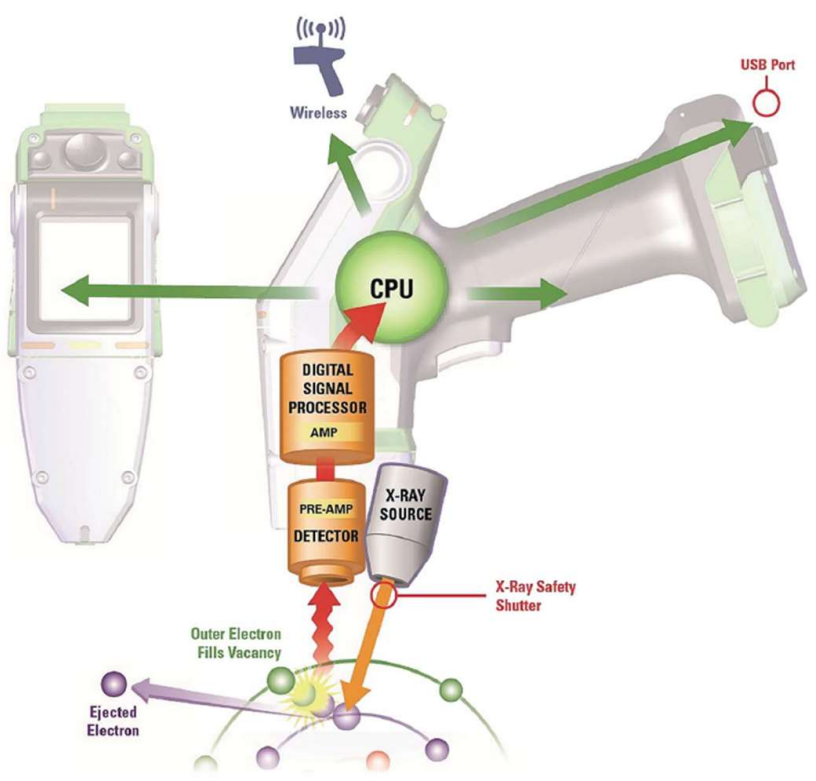

Figure 5. Schematic diagram showing the configuration of a typical hand-held XRF analyzer (Reproduced from Analytical Methods Committee AMCTB No. 89, 2019) 


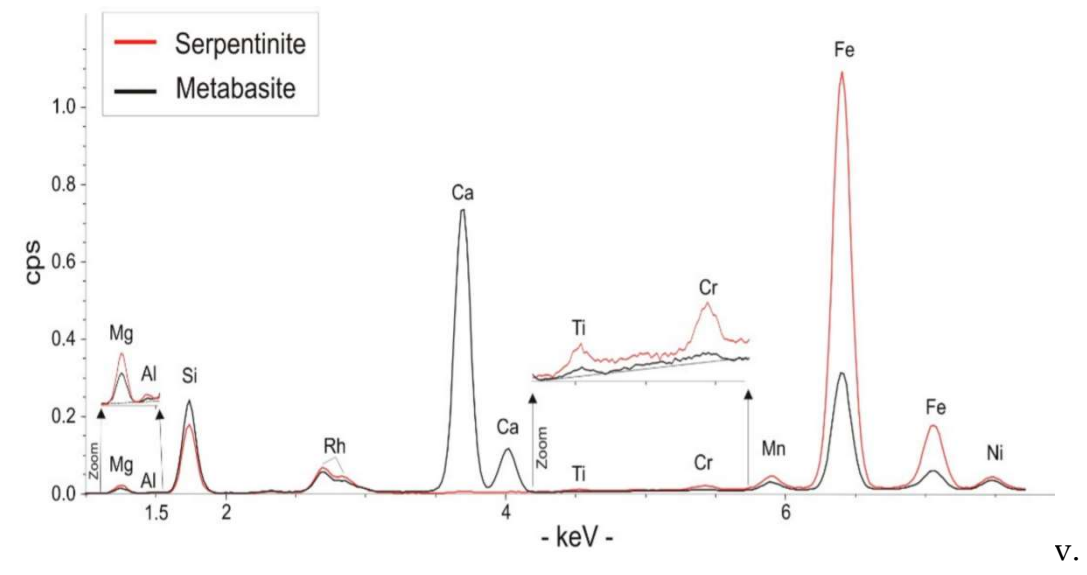

Figure 6. Portable XRF spectra of serpentinite and metabasaltic rocks (Reproduced from Bloise and Miriello, 2018).

\subsection{1. $\mathrm{pXRF}$ in mineral exploration using surface sediments}

pXRF methods of exploration were tested in northern Finland using surface till as a sample material for gold, Ni and PGE using pathfinder elements ( $\mathrm{Al}, \mathrm{Fe}$ and $\mathrm{Mg}$ ) of hydrothermal alteration (Sarala, 2009). The pXRF analyses of some major $(\mathrm{Ca}, \mathrm{Fe})$ and most of the base metal elements (like $\mathrm{As}, \mathrm{Cr}, \mathrm{Cu}, \mathrm{Mn}, \mathrm{Ni}, \mathrm{Pb}, \mathrm{Zn}$ ) correlate well with the aqua regia geochemical data of the same elements. Distribution of these elements was comparable to the lithological changes in the underlying bedrock demonstrating the utility of pXRF in collecting the geochemical data for tracing sources of multi-metal mineralization. For gold exploration studies by $\mathrm{pXRF}$, indicator elements like $\mathrm{As}, \mathrm{Bi}, \mathrm{Cu}, \mathrm{Mn}$ and $\mathrm{Sb}$ have to be used instead of Au because of its high detection limit (Table 2) for gold (Sarala, 2016). Somarin et al. (2021) demonstrated that a pXRF can produce data of good correlation with the laboratory analysis while utilizing the technique for Ta-Nb-Sn-W ore exploration studies.

\subsection{2. $\mathrm{pXRF}$ in Li exploration}

Unfortunately, $\mathrm{Li}$ and Be are not accessible by this technique as lighter elements have the fluorescent $\mathrm{X}$-ray energy levels that are low enough to escape from the sample to reach the detector without being absorbed. Even if they escape the sample, some of them will not be able to penetrate the air between the sample and the instrument to reach the detector. There must be a recognizable peak within the background noise for the element concentration to be calculated, and with the low energy light elements this is a challenge. Though pXRF can't determine $\mathrm{Li}$, it can accurately detect several pathfinder elements of lithium such as $\mathrm{Cs}, \mathrm{Ta}, \mathrm{Nb}, \mathrm{Sn} \mathrm{W}, \mathrm{K}$ and $\mathrm{Rb}$ (Table1) and thus can be extremely useful in the LCT pegmatite exploration studies. van de Ven (2020) used pXRF for obtaining internally consistent geochemical dataset of LCT-pathfinder elements (e.g., $\mathrm{Li}, \mathrm{Cs}, \mathrm{Ta}, \mathrm{Nb}, \mathrm{Be}$, $\mathrm{Sn}, \mathrm{W}, \mathrm{K}$, and $\mathrm{Rb}$ ) for an effective exploration strategy for LCT pegmatites in New Zealand to identify prospective pegmatites in an $1,831 \mathrm{~km}^{2}$ licensed area.

\subsection{3. $\mathrm{pXRF}$ in REE exploration}

Sedimentary phosphate deposits are the main sources of raw materials for the phosphate fertilizer industry. But in recent times, these phosphate deposits have been identified as potential sources for REE. Portable XRF was used in the first stage of an orientation survey for sedimentary phosphate occurrences containing REE in South-eastern British Columbia, Canada. The data was used to identify zones of phosphate rocks enriched in REE (Simandl et al. 2014). Uranium and thorium concentrations can also be monitored by pXRF to eliminate zones containing high concentrations of these elements for fertilizer 
industry as these radioactive elements can potentially get accumulated in agricultural soils and even eventually get into the food crops in high concentrations.

\subsubsection{Gold and PGE exploration studies using pXRF}

Portable XRF was found to be a powerful exploration tool for gold and PGE exploration studies. Determination of low concentration of desired elements in ore samples is commonly challenging due to matrix effects and peak overlaps. But in several cases, there is a very good correlation between the data obtained by pXRF in the field, and the laboratory data obtained by established techniques such as ICP-MS (e.g., Somarin and Steinhage, 2021). While pXRF instruments may not work well to detect low concentrations of precious metals, they can be excellent for detecting some pathfinder elements like $\mathrm{Cu}, \mathrm{Mg}$ and Ni. pXRF was successfully utilized to identify the anomalous zones of PGE and Au (target elements) using pathfinder elements $\mathrm{Ni}$ and $\mathrm{Cu}$ in the exploration of the Pilanesberg PGE deposit, Bushveld Complex, South Africa. 63 core samples were analyzed using both pXRF and laboratory methods. In these samples, $\mathrm{Pt}<8 \mu \mathrm{g} / \mathrm{g}, \mathrm{Pd}<5 \mu \mathrm{g} / \mathrm{g}$ and $\mathrm{Au}$ $<1 \mu \mathrm{g} / \mathrm{g}$, which were not detected by $\mathrm{pXRF}$; however, $\mathrm{Ni}$ and $\mathrm{Cu}$ are up to 6540 and 3560 $\mu \mathrm{g} / \mathrm{g}$, respectively, which were easily detected by the same method. These elements show positive correlation with the precious metals indicating that they can be used as pathfinders. Sometime back Robertson and Feather (2004) developed an automated energy dispersive XRF which took the detection limit of gold to $<1 \mu \mathrm{g} / \mathrm{g}$. This is very competitive to the well-established fire-assay methods (Balaram and Subramanyam, 2022). If this technology is made available for the current $\mathrm{pXRF}$ technology, it will be very handy for the gold mining industry in future. Lemiere, (2018) provided a comprehensive review of pXRF applications for applied geochemistry studies related to real-time decisions on exploration, mining, site remediation or waste management.

\section{Portable X-ray diffraction spectrometer (pXRD)}

pXRD provides geologists with a reliable, qualitative, and quantitative mineralogical data in near real time in the field. $\mathrm{pXRD}$ is a more definitive mineral identification technique that can identify and quantify a wider range of minerals compared to either SWIR reflectance spectroscopy or Raman spectroscopy. Figure 7 depicts a schematic diagram and a prototype instrument of a handheld back-reflection ED-XRD technique. XRD is based on crystal constructive interference of mono-chromatic X-rays and a crystalline sample, following the Bragg's Law. When a monochromatic X-ray beam passes through the sample crystal lattice, some of the radiation is diffracted at an angle known as Bragg angle and reaches the detector, which is equal to half the angle of the incident radiation. Each crystalline material has a characteristic atomic structure which is seen in the X-ray diffraction pattern. The peak positions in an XRD spectrum provide information on the spacing of the unit cell as well as its symmetry, which is crucial information for crystal identification. Hansford and Thomas (2015) presented a detailed account of the development of energy dispersive XRD. The portable XRD allows rapid mineral identification in the field, but can only analyze powdered rock samples. The technique can easily distinguish between minerals and recognizes them because of their differing crystal structures. The instrument only requires about $15 \mathrm{mg}$ of powder sample and the sample preparation is also very easy, and accurate mineral data can be obtained in a few minutes. From the diffractograms obtained (e.g., Figure 8) one can identify the minerals in the rock samples under testing. Modern XRD instruments are very compact in size and rapid, accurate, and have the ability to perform automated mineral analysis providing useful information in exploration, mining and beneficiation studies. Current global lithium production is derived from lithium-bearing pegmatites and lithium brines often concentrated in economic mining sites. pXRD can identify the number of Li-bearing minerals (Table 1) in LCT pegmatites (Trueman and Cerny, 1982). Figure 8 depicts a XRD pattern of lithium mineral, petalite (95\% quartz and 5\% petalite). Pöllmann and König, (2021) calculated the lithium 
content from quantitative mineralogical analysis using pXRD which led to a fast and reliable lithium determination in the ores and concentrates during lithium exploration studies. With several advancements in instrumental components such as X-ray tubes, detectors and processors, and more powerful software packages, currently the pXRD has become a highly reliable qualitative and quantitative mineralogical tool with potential applications in exploration and mining.
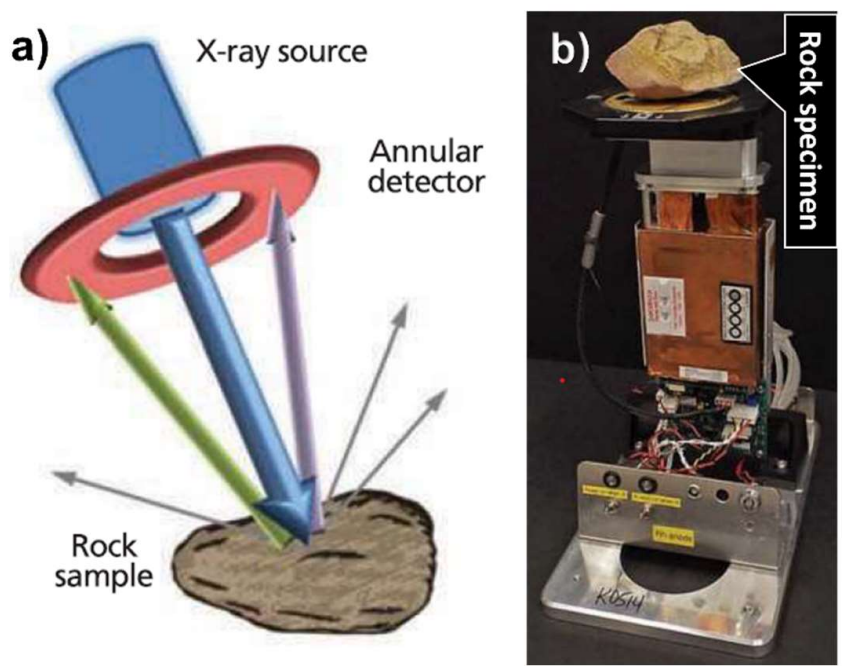

Figure 7. Schematic diagram of a handheld back-reflection EDXRD technique, b) photograph of the handheld back-reflection EDXRD system (Reproduced from Hansford and Thomas, 2015).

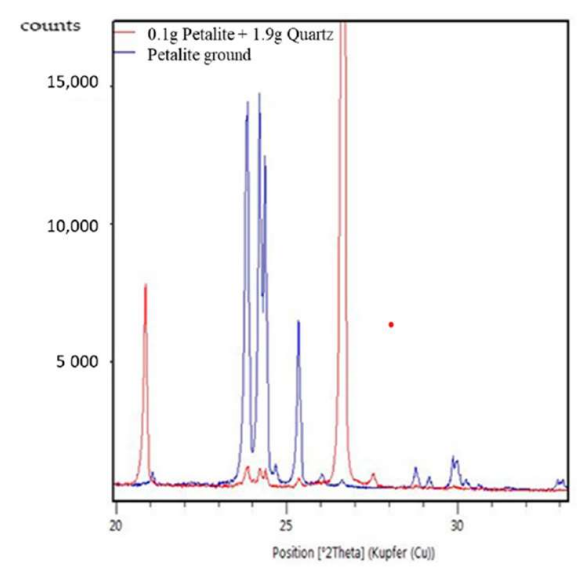

Figure 8. XRD pattern of lithium mineral, petalite (95\% quartz and 5\% petalite) (Pöllmann and König, 2021).

\section{6. pLIBS}

This instrument was developed commercially only around 2014 (Connors et al. 2016). In recent years, there is a surge in the application of LIBS technology as a result of the development of more compact, even portable systems that enable in-field use. pLIBS is an emerging low-cost portable geochemical and mineral exploration analytical tool that can provide rapid, in-situ, compositional analysis and high-resolution imaging in the field. This technique enables rapid chemical analysis of a wide range of materials including all kinds of geological samples at a level of precision of $\sim 5-20 \%$ RSD (Hark and Harmon, 2014). The LIBS technology utilizes a short and high energy laser to ablate the surface of the sample creating a plasma of small amounts of ablated material. The interaction between focused laser pulses and the sample material creates plasma composed of ionized 
matter with laser ablation craters of the order of 30 - $400 \mu \mathrm{m}$ diameter, depending on the laser wavelength. The extremely high temperatures within the plasma $(>100,000 \mathrm{~K})$ cause the ablated material to dissociate, atomize and ionize, and during the cooling process the characteristic atomic emission lines are emitted in the spectral region 200-1100 nm and these emissions can provide "spectral signatures" of chemical composition of the sample material (solid, liquid, or gas state). Each element of the periodic table produces a LIBS spectral peak unique to itself which allows for simultaneous multi-elemental analysis of most elements in the periodic table including lighter elements such as Be and Li which is not possible by pXRF. By using a detector to measure the unique characteristic of light emitted, it is possible to detect what elements are present within the sample. It's a near non-destructive technique as only a minute amount of sample is ablated and removed from the sample specimen during analysis. LIBS also has the ability to provide depth profiles. A schematic diagram of LIBS is shown in Figure 9 which involves a laser source, spectrometer (usual range, 200-1100 $\mathrm{nm}$ with $0.1 \mathrm{~nm}$ resolution) an intensified CCD (ICCD) detector or CMOS detectors with a minimum gate time of $\sim 1$ millisecond. Nd:YAG (yttrium aluminum garnet) is the most common laser used for pLIBS due to its relatively high efficiency and good thermal conductivity (Mukhopadhyay, 2011). Sample can be a direct rock sample or a sample powder pallet just as in case of laboratory XRF, and the sample thickness should be a minimum of 40 micrometers (corresponding to common thin rock sections). For geochemical analysis by LIBS, $193 \mathrm{~nm}$ excimer lasers and $213 \mathrm{~nm}$ $\mathrm{Nd}$ : YAG lasers are normally preferred among nanosecond-duration lasers. pLIBS is capable of qualitative, semi-quantitative, and quantitative analysis of most of the elements in the periodic table. Detection limits are typically in the low $-\mu \mathrm{g} / \mathrm{g}$ range (Figure 10) for most elements in the periodic table. However, the detection limits are highly dependent on the type laser, spectrometer, and the sample matrix used for analysis (Buckley, 2021). For example, higher absolute detection limits can be obtained by using femtosecond lasers, their high cost prohibits their use in portable LIBS instruments and femtosecond lasers are usually used only in the lab instruments (Buckley. 2021). A typical LIBS spectrum in the entire wavelength range obtained from different Li-rich minerals can be seen in Figure 11. Individual emission peaks of different elements are clearly seen. Thus, the emission spectra generated by LIBS can serve as the chemical signature of materials for the purpose of 'geochemical fingerprinting' which can provide information of the chemical composition of a mineral or a rock, and also the geological processes associated with its formation (Hark and Harmon, 2014). In most cases, solid samples can be directly analyzed by LIBS without any pretreatment. However, sometimes in order to obtain accurate, precise and reliable data, a minimal sample preparation is required. These approaches can be a simple mechanical separation of the test portion, cutting and polishing in order to access a homogeneous sampling region. More details on the sample preparation of solid as well as liquid samples for LIBS analysis are provided by Andrade et al. (2020). Because of these excellent performance characteristics, LIBS has wide potential to be utilized in mineral exploration, prospect evaluation, and mining studies. pXRF cannot measure elements lighter than $\mathrm{Al}(\mathrm{Z}=13)$, while there is no such limitation for pLIBS. The technique is particularly useful for the analysis of light elements of low ionization energy (e.g., $\mathrm{Mg}, \mathrm{Na}$, $\mathrm{C}, \mathrm{B}, \mathrm{Be}$, and $\mathrm{Li}$ ), some of which are important target elements as well as pathfinder elements for mineral exploration. Thus, these two analytical techniques are complementary for geochemical analysis. Harmon et al. (2019) recently gave a detailed account of the application of LIBS and pLIBS for mineral exploration studies and also for unraveling the complex geological history of most ore systems. pLIBS can also do the analysis of mineral and element distribution mapping within a sample when the analyzer was set up to perform a small step raster pattern. The element maps can be created for various elements by integrating the peak area measured for a particular element for each physical location measured. More details are provided by Connors et al. (2016).

Measurements of REE are sometimes difficult due to weak emission lines but several authors showed examples for a successful detection of the number of different REE in 
different geological materials (e.g., Rethfeldt et al. 2021). Recently a new type of LIBS system was developed without a built-in temporal gating, using a Nd-YAG laser beam as an excitation source and a highly temporally resolved optical detector system with a compact, low-cost optical multichannel analyzer (OMA) system. The practical analysis results on several types of samples including geological materials were encouraging (Idris et a. 2020). Harmon et al. (2019) described the recent advances in both laboratory and fieldportable LIBS for mineral exploration studies through rapid, qualitative to quantitative geochemical analyses.

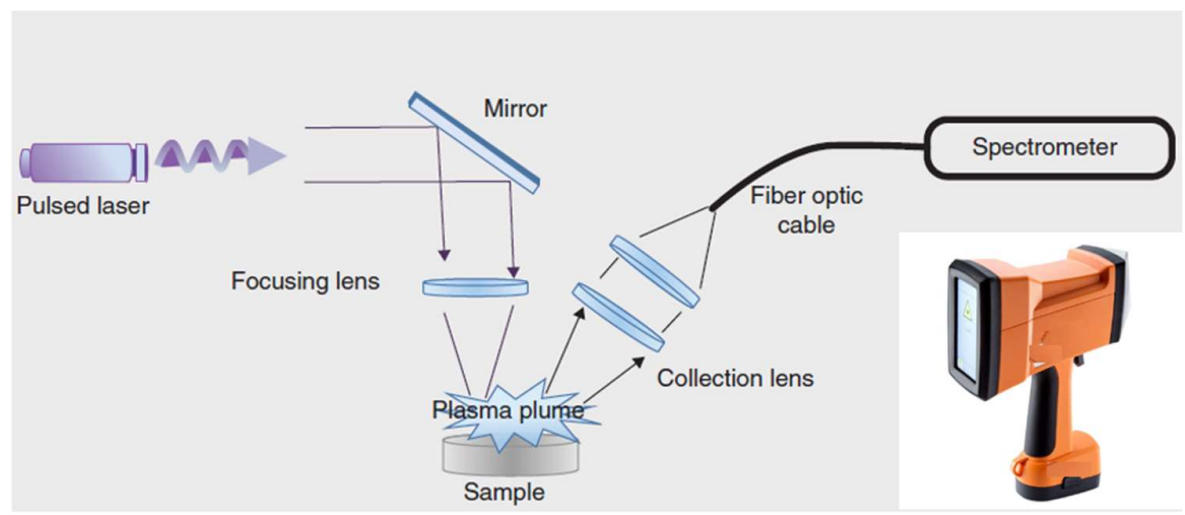

Figure 9. Detection limits for different elements obtainable by a commercial LIBS system (Buckley, 2021).

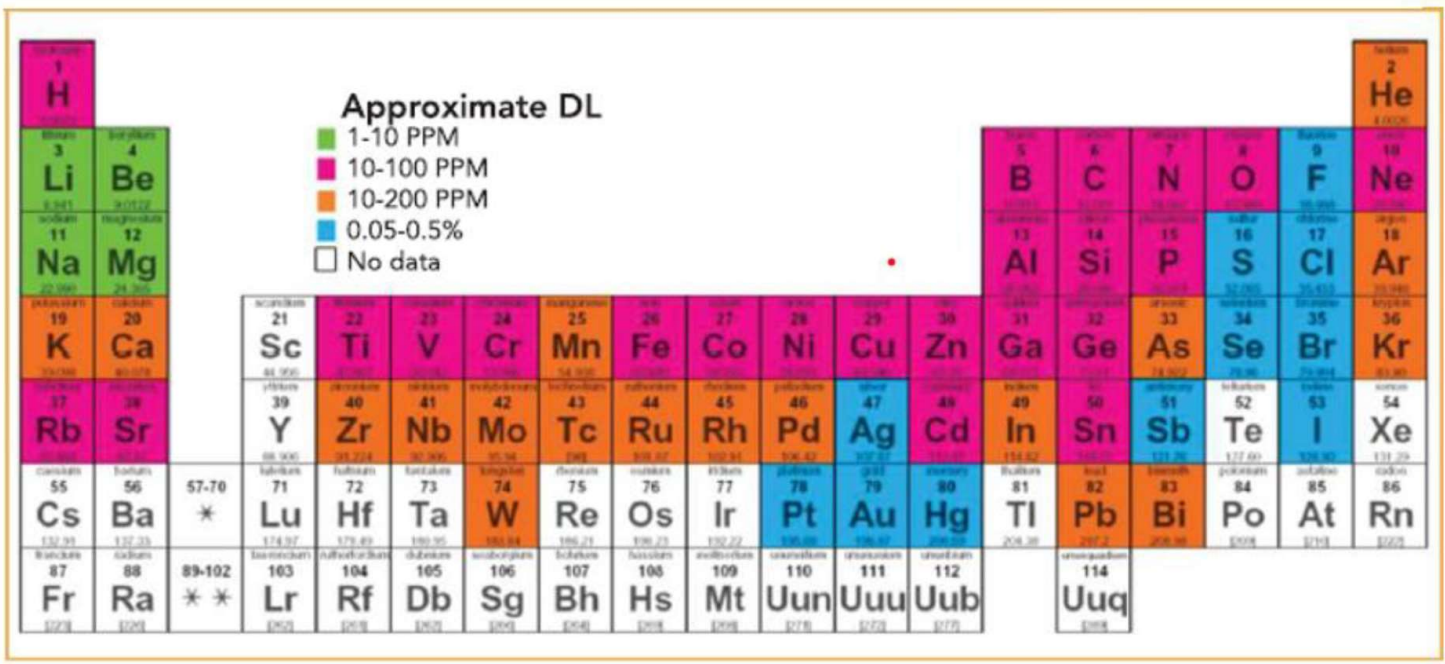

Figure 10. Detection limits for different elements obtainable by a commercial LIBS system (Buckley, 2021). 


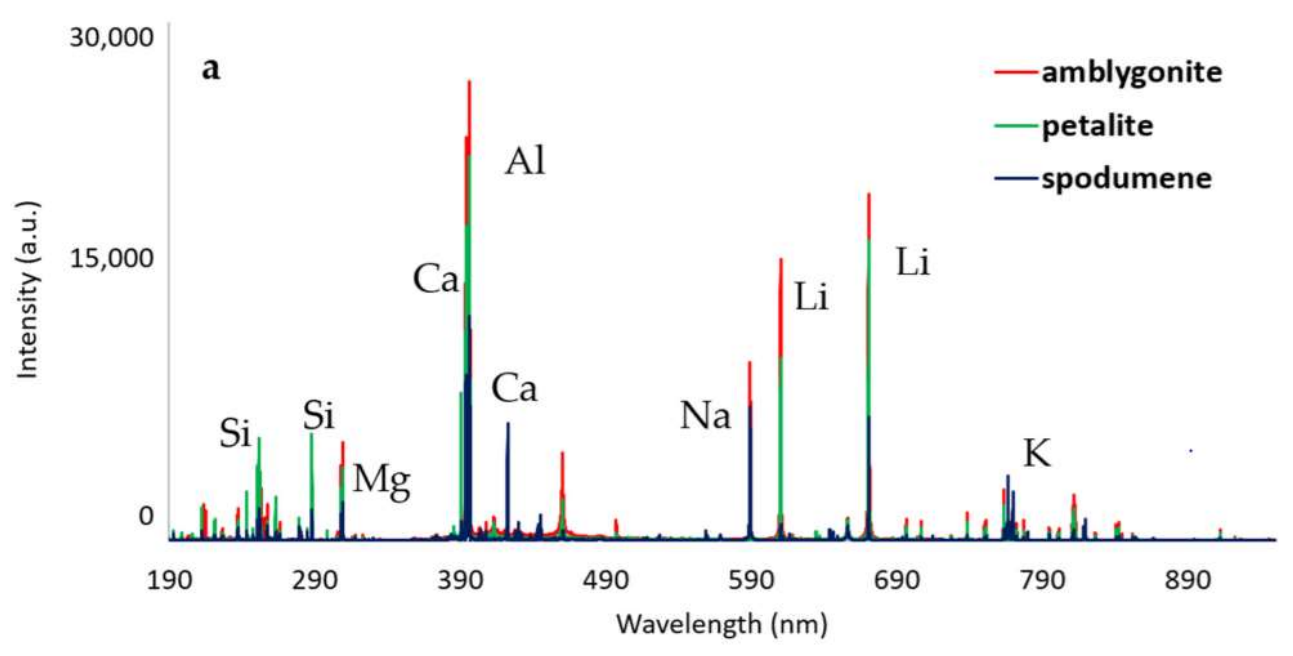

Figure 11. LIBS spectra in the entire wavelength range obtained from different Li-rich minerals (Fabre et al. 2021).

\section{1. $p L I B S$ to trace gold provenance}

Handheld LIBS devices can be used for rapid in-situ analysis of gold, thereby serving as a field-based decision-making tool. The best pathfinder element to trace gold mineralization is gold itself because it is dense, chemically stable and easily found in the erosional products of gold systems (i.e., alluvial gold from placers). Indeed, drainage sediment sampling, often the first step in a gold exploration strategy, is to detect the silver (Ag) content or its mineral inclusions at its most intense emission line at $546.58 \mathrm{~nm}$, in order to establish a link between a secondary (placer) deposit and its potential primary deposit. (Pochon et al. (2020). Results obtained in this study also demonstrated that it is possible to discriminate distinct populations of gold in concentrates/gold bullion to trace the origin of gold from the area of French Guiana gold districts which is affected by illegal mining. This is done by the principal component analysis (PCA) on the dataset obtained on other elements commonly associated with native gold, such as $\mathrm{Cu}, \mathrm{Zn}, \mathrm{Ag}$, $\mathrm{Pb}, \mathrm{As}$, Se, $\mathrm{Sb}, \mathrm{Sn}, \mathrm{Hg}$, and Te. This feature of pLIBS has some advantages over laboratory-based laser ablationICP-MS (LA-ICP-MS) for tracking illegal gold mining in addition to several other advantages such as it is less expensive, faster and convenient than by laboratory-based laser ablation-ICP-MS technique (Walting et al. 2014). Such studies also help in distinguishing gold sources and potentially yield insights into geochemical processes operating during gold deposit formation (Kerrich et al. 1997). Harhira et al. (2017) obtained a practical detection limit of $0.75 \mu \mathrm{g} / \mathrm{g}$ in gold bearing rocks and also in drill core samples demonstrating the potential of the techniques for gold exploration studies.

\section{2. pLIBS in Li-exploration studies}

Currently lithium is in high demand due to rapidly growing production of electric vehicles that use Li-ion batteries. It is produced from hard rock mines by countries like Australia, and from brine mines by Argentina, Chile and China. Li-exploration studies were carried out in the outcrops mainly consisting of pegmatites. LCT pegmatites (containing $\mathrm{Li}-\mathrm{Cs}-\mathrm{Ta}$ ) are an important source of $\mathrm{Li}$. Such pegmatites can have varying degrees of enrichment in $\mathrm{Li}, \mathrm{Rb}, \mathrm{Cs}, \mathrm{Be}, \mathrm{Sn}, \mathrm{Ga}, \mathrm{Ta}>\mathrm{Nb}, \mathrm{B}, \mathrm{P}$, and $\mathrm{F}$. The crustal abundance of $\mathrm{Li}$ is $17 \mu \mathrm{g} / \mathrm{g}$, but the concentration in the mineralized rocks can go up to $\sim 3 \%$ (Wise et al. 2022). Hyperspectral imaging data (HSI) generated by portable VNIR, and SWIR spectrometer was also utilized for Li exploration studies. pLIBS is an ideal geochemical tool for $\mathrm{Li}$ exploration because it is the only technique that can measure Li concentration in 
minerals, rocks, soils, and brines in-situ in the field. Figure 11 presents the LIBS spectra of three Li-rich minerals obtained from different Li-rich minerals in the entire wavelength range (Pochon et al. 2021). Wise et al. (2022) recently demonstrated the potential of pLIBS in the LCT pegmatites of the Carolina Tin-Spodumene Belt (CTSB) situated in the Kings Mountain Shear Zone, USA. pLIBS was utilized for the identification and quantification of lithium (detection limit $<100 \mu \mathrm{g} / \mathrm{g}$ ), measurement of $\mathrm{K} / \mathrm{Rb}$ ratios, lithium mapping, and depth profiling. Use of pLIBS drastically reduced the time necessary to acquire the required geochemical data during a Li pegmatite exploration program.

\section{7. $\mu$. Raman analyzer}

Exploration scientists understood that there is great need to utilize innovative techniques in mineral exploration studies to unearth the hidden mineral deposits, and realized the remarkable capability of the $\mu$ Raman spectrometer, in obtaining chemical and mineralogical information (Balaram, 2017). Levitan et al. (2009) realized the importance of Raman spectroscopy as it was very effective in distinguishing among the serpentine-group minerals, chrysotile, antigorite, and lizardite, which have similar XRD patterns. Thus, Raman spectrometers deliver both chemical composition and structural information in a single measurement. $\mu$ Raman spectrometer is also a nondestructive portable analytical technique and out of the techniques described here, it is the only technique which can identify both inorganic and organic compounds without the need for any chemical or mechanical sample preparation. Figure 12 is a schematic diagram of a modern portable Raman spectrometer. A visible light or UV or IR from a laser source is delivered through a lens and a filter. The light is then reflected by a mirror and focused onto the sample through a microscope objective lens where the laser light interacts with molecular vibrations, phonons or other excitations in the system, resulting in the energy of the laser photons being shifted up or down. This shift in energy is known as the "Raman effect" which is detected by the detector providing information about the vibrational modes in the system (sample). Thus, the Raman spectrum can be regarded as the fingerprint of the molecule and it is evidently a non-destructive technique. The typical spectral resolution of a handheld spectrometer is around $10 \mathrm{~cm}-1$, which is contrasted to the typical values of $1-2 \mathrm{~cm}-1$ for full-fledged laboratory spectrometers. Laboratory based instruments were commercially available in the late 1980s, and currently miniaturized instruments which can be taken to the field are also available. Visual identification basing on of their specific physical properties such as color, hardness, and cleavage, as well as their crystal structure can be relatively simple for some minerals in field, but for many common rock forming minerals, special equipments such as pXRD or $\mu$ Raman spectrometer are necessary. Sergeeva et al. (2020) using portable Raman spectrometer discovered a complex mineral called, ammoniovoltaite, (NH4)2Fe2+5Fe3+3Al (SO4)12(H2O)18 in a complex hydrated sulphate of the volatile group on the surface of the Severo-Kambalny geothermal field, Kamchatka, Russia. In another example, Raman micro-spectroscopy with visible $532 \mathrm{~nm}$ wavelength excitation confirmed the biogenic presence of the cyanobacterial mat which had a significant impact on the formation of the unique Nb-REE Tomtor deposit, Russia (Moroz et al. 2021). Figure 13 shows Raman spectra of some common heavy minerals of different origin. Generally, for the identification of serpentine minerals in rocks, carried out by scanning electron microscopy - energy dispersive spectrometry (SEM-EDS) and transmission electron microscopy (TEM), both of which are very expensive and require complicated sample preparation procedures. Groppo et al. (2006) used less expensive micro-Raman spectroscopy to accomplish this task which also requires no sample preparation. Recently Orlando et al. (2021) gave a comprehensive account along with various applications of Raman spectroscopy.

Carbonate rocks act as reservoirs in sedimentary rocks and can also be host rocks related to numerous metalliferous ore deposits in magmatic, hydrothermal, or sedimentary environments. Kim et al. (2021) analyzed the spectral features associated with the 
identification and compositional variation of $\mathrm{Ca}-\mathrm{Mg}-\mathrm{Fe}-\mathrm{Mn}$ natural carbonate minerals with a calcite structure (calcite, ankerite, dolomite, siderite, rhodochrosite, and magnesite) by using a portable Raman device with a $532 \mathrm{~nm}$ excitation laser, and a portable infrared spectrometer with ATR (Attenuated Total Reflection). These authors demonstrated a strong correlation between $\mathrm{Mg} \#$ acquired from a portable XRF device and the band positions from both a portable Raman and a portable IR spectrometer.

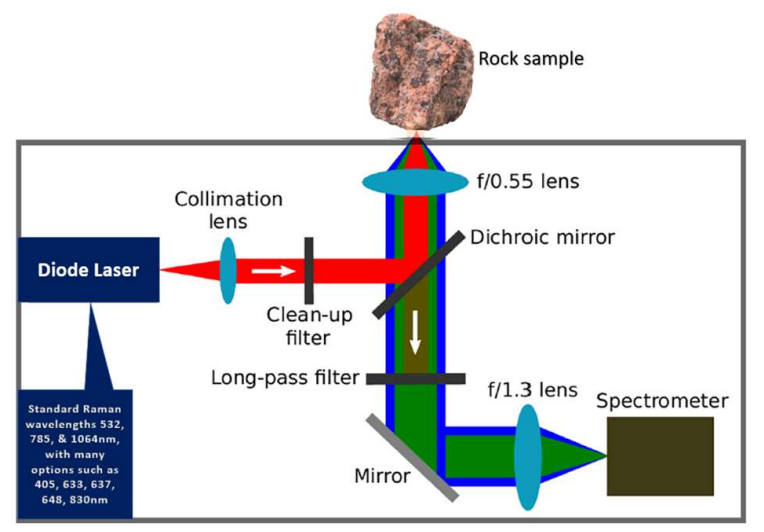

Figure 12. Raman spectra of some common heavy minerals of different origin (Reproduced from Ando and Garzanti, 2013).
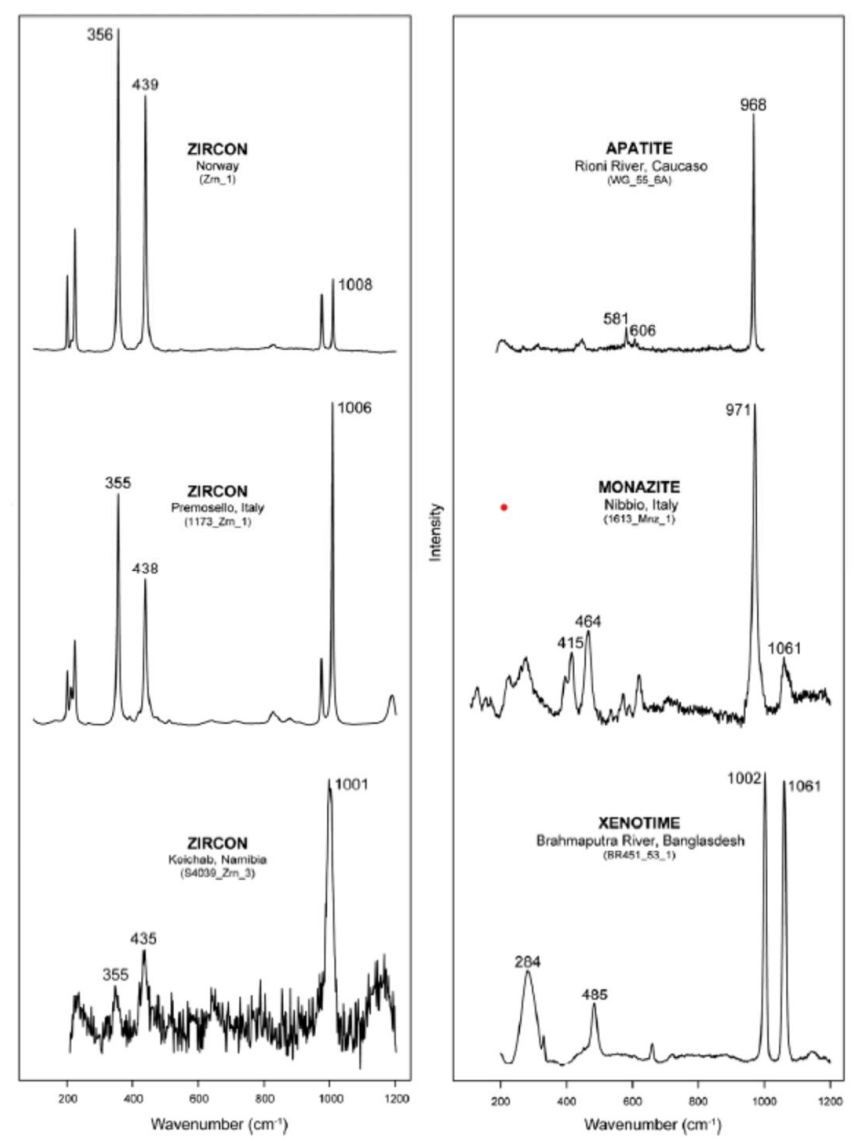

Figure 13. Raman spectra of some common heavy minerals of different origin (Reproduced from Ando and 849 Garzanti, 2013). 


\section{Core scanners}

Core scanner technologies are based on XRF, LIBS, and IR hyperspectral (HS) sensors to obtain petrophysical, mineralogical and geochemical data in general (Dunlea et al. 2020; Rosa et al. 2021; Paradis et al. 2021). These core scanners provide rapid scanning of drill cores that are extracted from a drill hole, and provide high-resolution analytical data to identify sweet spots, mineralization, and alteration. LIBS is a promising technology for fast detection of enriched areas in drill cores and easy to apply to numerous core sections on the mining site allowing detailed interpretations relevant for the genesis of mineralisations and metal distributions, based on a comprehensive dataset. The LIBS technique is much faster than other time-consuming methods, such as electron probe micro analyzer (EPMA) and LA-ICP-MS. Recently LIBS with its capability to provide both high-resolution and low-resolution data, proved to be a high performance and high-speed drill core scanner (Paradis et al. 2021). LIBS-based core scanner was used to investigate continuous spatially resolved variations in the chemical and mineralogical composition of chromitite ore from Merensky Reef ore, Bushveld complex, South Africa, from the sub-millimetre to the meter scale, and could well distinguish between several base metal sulphides, rockforming minerals, and accessory minerals (Meima and Rammlmair, 2020). LIBS technology also suffers from matrix effects just like any other spectroscopy technique. As similar mineral phases will produce similar LIBS spectra with similar matrix effects, classification, therefore, seems very effective for handling matrix effects in LIBS-based images of coarsegrained geological samples. The technique can provide semi-quantitative elemental data for well-defined phases using point counting, and the technique can also detect $\mathrm{Pt}$ and $\mathrm{Pd}$ when they occur in nuggets. Core scanners based on LIBS technology also provided elemental ratios such as $\mathrm{Mg} / \mathrm{Fe}, \mathrm{Cr} / \mathrm{Al}$ and $\mathrm{Ca} / \mathrm{Na}$ ratios which were successfully validated by EPMA on multiple polished sections (Meima et al. 2022). The new LIBS scanner can scan a drill core of about $4 \mathrm{~m}$ in less than $5 \mathrm{~min}$, generate the mineral and chemical maps at representative resolutions, and provide high-resolution optical photographs (Paradis et al. 2021). Thus, core scanners based on LIBS technology provide on-site and real-time information, and contribute to exploration success.

\section{Portable multi-analytical devices, and micro analytical devices to explore terrestrial, and extra- terrestrial rocks}

In order to study the surface rocks of Mars, the National Aeronautics and Space Administration (NASA), USA, sent the Perseverance Rover with a suit of miniature analytical instruments in different modules known as Mastcam-Z, MEDA, MOXIE, PIXL, RIMFAX, SHERLOC, and SuperCam, in which PIXL contains micro-XRF to determine the fine scale elemental composition of Martian surface materials, and SHERLOC contains micro-UV Raman spectrometer to provide complementary measurements with other instruments in the payload (Rull et al. 2021). In the earlier Curiosity Rover, there was a module known as ChemCam (Chemistry \& Camera). ChemCam is actually two different instruments combined as one: a LIBS and a Remote Micro Imager (RMI) telescope. The purpose of the LIBS instrument is to provide elemental compositions of rock and soil, while the RMI will provide high-resolution images of the sampling areas of the rocks and soil that LIBS targets (e.g., Rammelkamp et al. 2021). Such combinations of miniature instruments are also available commercially for the studies of terrestrial rocks. One of the most popular and extremely valuable combinations for obtaining both geochemical and mineralogical information of geological materials is a micro-XRF and a micro-XRD in one instrument which complement each other (Gonzalez-Fernandez et al. 2011). These kinds of instruments can be operated in single and/or multi-modes, and provide more complementary information from the same sample in a shorter time leading to faster and sometimes more reliable results in the field, than data obtained from traditional instrumental methods. For example, during Li-exploration studies, pXRD technology can detect most lithium minerals (Table 1) and provide a complete picture of the pegmatite mineralogy. A combination of 
pXRD and pXRF, may be more useful where the crystal structures are similar but differ in their elemental composition as pXRD is only sensitive to spacings. Bloise and Miriello, (2018) used a portable multi-analytical device, which combines portable digital microscopy (p-DM), pXRF and a $\mu$ Raman analyzer to analyze serpentinite and metabasite rocks containing asbestos. The portable digital microscope enabled it to distinguish fibrous and other morphologies. pXRF was used to obtain the in-situ rapid chemical discrimination of serpentinite and metabasite rocks. Finally, the chrysotile and tremolite asbestos were easily identified due to their characteristic Raman spectrum. Dhanada et al. (2020) recently reviewed the development of different combinations of instruments having laser as a source like LIBS, Raman spectroscopy and laser induced fluorescence spectroscopy (LIF) systems into portable/miniature assemblies in future. Thus, this kind of combinations provided remarkable improvements and advantages over conventional techniques during the last three decades and significantly broadened their applications in the analysis of geological materials (Balaram, 2021a). In fact, such combination instruments normally increase our ability to interpret the data collected and help in the successful exploration programs.

\section{Role of portable analytical tools/sensors in deep-sea exploration}

As the land-based mineral deposits are producing lower grades at higher production costs, and new discoveries are becoming harder to locate, exploration scientists started looking towards oceans for the critical minerals and metals. Deep-sea hydrothermal areas, polymetallic nodules and crusts, and marine mud which are widely distributed all over the world contain abundance of metal resources which have become the focus of marine research in recent years. Though the deep-sea mining companies have not started their operations on a commercial-scale in international waters due to environmental concerns, some feel that deep-sea mining becomes investable in future for the supply of minerals/metals for the green energy revolution (Miller et al. 2021). However, a lot of exploration studies are going on worldwide. Seafloor REE deposits occur in environments with low sedimentation rates, from shallow continental shelves to deep abyssal plains, where they are typically adsorbed onto iron manganese nodules, crusts or muds (Takaya et al. 2018). Spectroscopic techniques, especially the miniaturized devices are currently expanding their horizon from Mars in the Solar system to the deep-oceans. pXRF devices for the characterization of REE are extremely valuable for offshore quantification and strategies during expedition cruises (Milinovic et al. 2021). In addition, the emergence of underwater remotely operated vehicles (ROV) equipped with chemical sensors, such as LIBS, Raman spectrometer, near IR spectrometer, and laser induced fluorescence spectrometer for insitu detection started showing their potential to be used in deep-sea geological explorations. Because of the highly sensitive and selective detection capabilities, some of these miniaturized spectroscopic techniques are getting deployed in ROV in deep marine environments to perform in-situ multi-element geochemical analysis of both seawater and mineral deposits on the ocean beds. In fact, for instruments like Raman spectrometer and LIBS underwater environments pose a lot of challenges such as plasma quenching effects due to the nearly incompressible fluid medium, which can significantly degrade the quality of the signals obtained. To overcome this, underwater LIBS systems will have doublepulse technique (Nyga and Neu, 1993). More details are provided by Thornton et al. (2015). Figure 14 shows the typical spectrum of a manganese nodule sample from deep sea in Jiaozhou Bay, China after background subtraction processing, the characteristic lines of major metallic elements of Fe and Mn can be observed clearly. Comparison of the data of seawater composition determined in-situ by LIBS and in the laboratory can be seen in Table 3. These results on the simultaneous determination of major elements $(\mathrm{Na}, \mathrm{Mg}$, $\mathrm{Ca}, \mathrm{K}$ ) and Li over a range of concentrations demonstrate that the deep-sea LIBS instrument has sufficient sensitivity and accuracy relevant to oceanic applications. Oceanic insitu sensors based on spectroscopic technology have many advantages, such as simulta- 
neous detection of multiple components, non-contact, high speed in analysis, wide adaptability, strong flexibility, and are becoming one of the hot topics in marine research (Liu et al. 2020). The demand for REE is increasing day-by-day with ever increasing applications of these metals in high technology products and the exploration activities for finding new resources have increased greatly in recent years. (Balaram, 2022). The most enriched REE mud has occurred in pelagic deep-sea regions more than 2,000 km from mid-ocean ridges, in depths greater than $4,000 \mathrm{~m}$. In an effort to find out an efficient way to explore the ocean floor for REE deposits, Obhođaš et al. (2018) developed two nuclear techniques for the in-situ measurements of REE in deep sea sediments: i) passive measurement of 176Lu radioactivity, which is appropriate if long-term in-situ measurements are possible, and ii) the use of the neutron sensor attached to a ROV for rapid in-situ measurement of gadolinium by thermal neutron-capture. As lutetium and gadolinium show strong linear correlation to the $\sum$ REE concentrations in deep sea sediments, it is possible to deduce the total REE content by measuring just $\mathrm{Lu}$ or $\mathrm{Gd}$ concentrations.

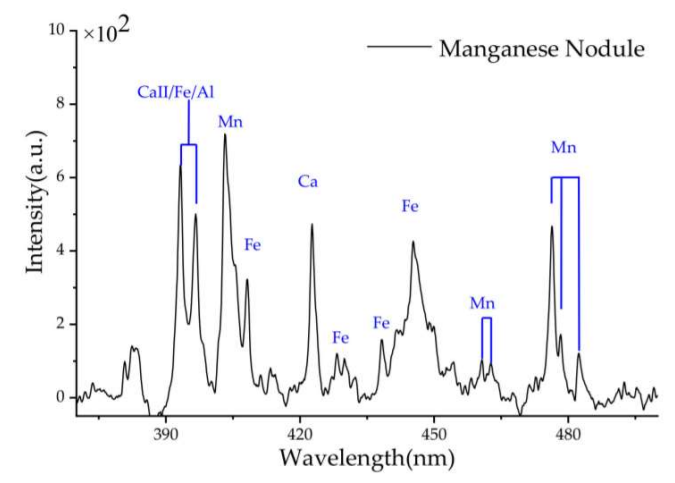

Figure 14. Different types of deposits, pathfinding minerals and elements.

Table 3. Comparison of seawater composition determined by in-situ determination by LIBS probe and analysis of the samples in the vicinity by ICP-AES in a laboratory (Thornton et al. 2015).

\begin{tabular}{ccclc}
\hline Description & $\begin{array}{c}\mathbf{N a} \\
(\mathbf{m m o l} / \mathbf{k g})\end{array}$ & $\mathbf{K}(\mathbf{m m o l} / \mathbf{k g}) \mathbf{C a}$ & $(\mathbf{m m o l} / \mathbf{k g})$ & $\mathbf{L i} \mathbf{~ I n ~}(\mu \mathbf{m o l} / \mathbf{k g})$ \\
\hline $\begin{array}{c}\text { In-situ determination by } \\
\text { LIBS }\end{array}$ & $470 \pm 2$ & $10.3 \pm 0.2$ & $9.7 \pm 1.0$ & $25 \pm 9$ \\
\hline $\begin{array}{c}\text { In Lab determined by ICP- } \\
\text { AES }\end{array}$ & 452 & 10.2 & 9.4 & 43.2 \\
\hline
\end{tabular}

Milinovic et al. (2021) used a pXRD for studying the mineral composition of marine sediments on-board ocean exploration cruises. The results were validated later on by using the conventional laboratory instruments after the exploration mission. It was shown that mineralogy could be efficiently assessed during the cruises at sea; i.e., within $20 \mathrm{~h}$, it was possible to analyze a batch of up to 24 gravity corer sediment samples. Milinovic et al. (2020) demonstrated that by using the portable infrared mineral analyzer (PIMA) using SWIR spectral analysis it is possible to get both qualitative and quantitative results of mineral components and geochemistry (e.g., La, Ce, Pr, Nd, Sm, Gd, Dy, Er, Yb, and Y) on board in previously studied ocean-floor areas, with high sensitivity. This instrument can also replace the destructive wet chemical sample digestion and extraction, and analysis by conventional ICP-MS (Balaram 2021b). Thus, obtaining empirical SWIR-reflectance data by SWIR spectral analysis in near real-time can be valuable in exploration of geochemical deposits in the ocean floor particularly to make any changes in exploration strategies

11. Challenges in data quality and ways to overcome 
Traditional laboratory-based instruments like WD-XRF, ICP-MS, and Raman spectrometer are normally housed in stationary locations with controlled environment and temperature. On the other hand, portable instruments such as pXRF, pLIBS and $\mu$ Raman spectrometers are normally used in variable temperature conditions and rugged environments in the field. For example, Iceland offers a range of environments, including volcanically active regions, extensive lava fields, geothermal springs, and large swaths of icecovered terrains, and in some counties across the globe, the temperature can go beyond 45oC. Bower et al. (2021) combined pLIBS, pRaman and UV/VIS/NIR spectroscopy to characterize the mineral assemblages, hydrated components, and biomolecules in rock and sediment samples collected from some sites in the volcanically active KverkfjöllVatnajökull region. However, the results obtained in the field do not always match with those obtained in the laboratory due to several reasons: i) the differences in environment including dust, ii) temperature differences iii) differences in sample preparation (sample geometry, density, grain size, and moisture), and iv) technical limitations of portable instruments. Laboratory sample preparation procedures ensure sample representativity which can be taken care of to some extent through grid or multiple measurements in field conditions. Thus, if these aspects are completely understood and proper attention is given to careful sample preparation and following appropriate quality procedures, the portable instruments can also provide reliable data in field conditions (Laperche nd Lemière, 2021). In the case of $\mathrm{pXRF}$, it is a surface/near surface technique that is assumed to penetrate down a few micrometers to several millimeters depending on the nature of the sample matrix, and only measures the portion of sample directly in front of the window. On several occasions, comparable data can be obtained by pXRF and laboratory instruments like ICP-MS on the same samples for certain elements such as $\mathrm{As}, \mathrm{Cu}$ and $\mathrm{Pb}$. However, for elements like $\mathrm{Sb}$ the agreement was not good because the concentrations of $\mathrm{Sb}$ were close to the lower limit of detection by pXRF (Arne et al, 2014). This much accuracy may be sufficient in exploration studies, particularly when looking for trends rather than very accurate values. But in other activities such as mining and grade control, greater care in sample preparation, instrument calibrations and quality control protocols are required for obtaining more reliable information. For LIBS element detection, the signal is usually sufficient for identification even if the sample is not strictly flat (for the scale of the window $3 \mathrm{~mm} \times 4 \mathrm{~mm}$ ). For $\mu$ Raman spectroscopy work, instrumental parameters such as focal plane precision, exposure time, and ambient light conditions in the field can affect the acquisition and interpretation of spectroscopic data from the specimens (Vitek et al. 2013). The real-time chemical and mineralogical analyses on drill cores by pXRF, pFTIR spectrometer, XRD and Raman spectrometer are challenging because of the drill core surface condition and sample heterogeneities. A study by Duée et al. (2018) revealed that the surface condition has minor influence on the results of the portable instruments. Their study also showed that a multi-technique approach was the best to overcome the drawbacks of the variations in the core texture.

There is no replacement for proper sample preparation, testing protocol, and following rigorous quality assurance and quality control (QA and QC) protocols by utilizing international matrix matching certified reference materials (CRMs) for obtaining accurate quantitative data (Balaram et al. 2006: Balaram and Satyanarayanan, 2022). This method minimizes matrix effects due to compatibility between sample chemical and physical characteristics and calibration standards. Other traditional calibration strategies such as standard addition (SA) and internal standardization (IS) can be utilized to reduce matrix effects (Balaram, 2021b). To minimize the influence of the matrix elements on a particular element, matrix-matched international CRMs are analyzed and correction factors are applied to get the most accurate data even in field conditions. Durance et al. (2014) used laboratory-based whole rock analyses of representative samples from a project area and matrix-matching international CRMs to derive correction factors to apply to pXRF data in order to ensure that data are both accurate and precise. Then, the results obtained by these 
portable instruments can many times match the data obtained by laboratory-based instruments provided the user is sufficiently experienced and generates the data with sufficient care, and then the data can constitute powerful data sets. Despite these facts, portable techniques are getting established and producing data with comparable accuracy with those of well-established laboratory-based analytical techniques (Bhatt et al. 2017). Fuchs et al. (2021) developed a data library consisting of high-resolution spectral information in the visible to near-infrared range (350-1080 nm) which will deal with spectral overlap effects and be useful for the identification of some element such as REE.

Users also must understand the dangers of x-rays, and lasers and know the fundamentals of radiation protection. Although LIBS and Raman instruments do not emit ionizing radiation, they do have open beam lasers, with consequent concerns about the eye's safety (Crocombe, 2018). pXRF requires licensing and operator safety training as it has an open beam X-ray source.

\section{Conclusions and future}

Exploration geoscientists and the mining companies are currently facing challenges of declining mineral reserves and increasing discovery costs. Geochemical exploration techniques both laboratory-based and field-based can provide an excellent support system in this endeavor in future to help the new discoveries of ore bodies at reduced environmental and exploration costs. Especially, the development of low-cost field portable analytical instruments such as portable short-wave infrared (SWIR) spectrometer, pXRF, pXRD, pLIBS and $\mu$ Raman spectrometer are allowing the possibility of obtaining geochemical and mineralogical information while engaged in field investigations over the last couple of decades allowing real time decisions to be made with reasonable confidence. These are extremely valuable not only in exploration, mining and processing studies, but also in quality control, trading and safeguarding the environment.

Recent success in the discoveries of new mineral deposits using these portable techniques have made these techniques very popular. The ability of these portable techniques, combined with the GPS and Bluetooth facilities, enables even more exciting applications such as physical mineral mapping across large areas in the field and instant data transmission back to a central database. In-situ analytical techniques are more appropriate and useful for the successful exploration, mining of deep-sea minerals, and to understand the ecosystem. They can be used for the analysis of rocks and soils with varied compositions with no or minimal sample preparation. However, clear understanding of the matrix interferences is extremely important for obtaining optimum results. Application of multivariate methods may be helpful especially for heterogeneous samples.

Portable XRF technology is currently established in exploration, mining, and metallurgical studies. Portable LIBS is one of the few techniques that can detect lithium as well as all the halogens in the field. Current developments in on-site analysis together with sound QA and QC protocols are increasing confidence levels of the exploration scientists. Laser technology is constantly improving with laser size reduction and pulse power enhancement, and with improved optics it is expected that there will be further progress in these portable laser-based instruments in future.

Acknowledgments: The authors thank the Director, CSIR-NGRI, Hyderabad, for the support and encouragement.

Conflicts of Interest: The authors declare no conflict of interest

\section{Appendix A}

The appendix is an optional section that can contain details and data supplemental to the main text-for example, explanations of experimental details that would disrupt the flow of the main text but nonetheless remain crucial to understanding and reproducing the research shown; figures of replicates for experiments of which representative data 
is shown in the main text can be added here if brief, or as Supplementary data. Mathematical proofs of results not central to the paper can be added as an appendix.

\section{References}

1. AMCTB, Analytical Methods Committee No. 89 Hand-held X-ray fluorescence spectrometry. Analytical Methods, 2019, 14 doi:10.1039/c9ay90060h

2. Ando, S., Garzanti, E. Raman spectroscopy in heavy-mineral studies, from Scott, R. A., Smyth, H. R., Morton, A. C. \& Richardson, N. (eds) 2014. Sediment Provenance Studies in Hydrocarbon Exploration and Production. Geological Society, London, Special Publications, 2013, 386, 395-412; http://dx.doi.org/10.1144/SP386.2

3. Andrade, D. F., Pereira-Filho, E. R., Amarasiriwardena, D. Current trends in laser-induced breakdown spectroscopy: a tutorial review, Applied Spectroscopy Reviews, 2020. DOI: 10.1080/05704928.2020.1739063

4. Arne, D. C., Mackie, R. A., Jones, S. A. The use of property-scale portable X-ray fluorescence data in gold exploration: advantages and limitations. Geochemistry: Exploration, Environment, Analysis, 2014, 14, 233-244; http://dx.doi.org/10.1144/geochem2013-233.

5. Azmi, H.; Moarefvand, P., Maghsoudi, A. Gold anomaly ranking based on stream sediment geochemistry in the FarimanKashmar axis, NE Iran. Acta Geochimica. 2020, doi:10.1007/s11631-020-00420-8

6. Balaram V, Patil M L, Agrawal A K, Suba Rao D V, Charan S N, Satyanarayanan M, Ramavati Mathur, Kapilavastu, K, Sarma DS, Sankara Gowda M, Ramesh S L Sangurmath P, Anjaiah K V, Dasaram B, Saxena R.K., Begum, Z. Preparation and certification of high-grade gold geochemical reference material, Accreditation and Quality Assurance, 2006,11: 329335; doi: 10.1007/s00769-006-0179-8

7. Balaram, V. Current Advances in Miniaturization of Analytical Instruments - Applications in Cosmochemistry, Geochemistry, Exploration and Environmental Sciences, Spectroscopy, 2016, 31 (10) 40-44.

8. Balaram V. Field-portable instruments in mineral exploration: Past, present and future, Journal of Applied Geochemistry, 2017, 19 (4) 382-399.

9. Balaram V. Current and emerging analytical techniques for geochemical and geochronological studies. Geological Journal, 2021a, 56, 5, 2300-2359. https://doi.org/10.1002/gj.4005

10. Balaram, V. Strategies to overcome interferences in elemental and isotopic geochemical studies by quadrupole ICP-MS: A critical evaluation of the recent developments. Rapid Commun. Mass Spectrom., 2021b, e9065, 1-29. doi: 10.1002/rcm.9065.

11. Balaram, V. Rare Earth Elements: Sources and Applications, in Environmental Technologies to Treat Rare Earth Elements Pollution: Principles and Engineering by Arindam Sinharoy and Piet N. L. Lens (Eds.), IWA Publishers, London, 2022, doi: 10.2166/9781789062236_0073

12. Balaram, V., Rahaman, W., Roy, P. Recent Advances in MC-ICP-MS Applications in the Earth, Environmental Sciences: Challenges and Solution, Geosystems and Geoenvironment, 2022, https://doi.org/10.1016/j.geogeo.2021.100019

13. Balaram V., Subramanyam, K. S. V. Sample Preparation for Geochemical Analysis: Strategies and Significance. Advances in Sample Preparation, 2022, 1, https://doi.org/10.1016/j.sampre.2022.100010

14. Balaram, V., Satyanarayanan, M. Quality assurance and quality control approaches in geochemical analysis, Accreditation and Quality Assurance, 2022 (under revision)

15. Barton, I.F., Gabriel, M.J., Lyons-Baral, J. et al. Extending geometallurgy to the mine scale with hyperspectral imaging: a pilot study using drone- and ground-based scanning. Mining, Metallurgy \& Exploration, 2021, 38, 799-818, https://doi.org/10.1007/s42461-021-00404-z

16. Baumgartner, R. J., Kunzmann, M., Spinks, S., Bian, X., John, S. C., Blaikie, T. N., Hu, S. Zinc isotope composition of the Proterozoic clastic-dominated McArthur River Zn-Pb-Ag deposit, northern Australia. Ore Geology Reviews, 2021, 139, Part B, 104545; https://doi.org/10.1016/j.oregeorev.2021.104545

17. Bayari, E. E., Foli., S.K. Y., Gawu. Geochemical and pathfinder elements assessment in some mineralized regolith profiles in Bole-Nangodi gold belt in north-eastern Ghana. Environmental Earth Sciences, 2019, 78:268 https://doi.org/10.1007/s12665-019-8265-5

18. Bharti, R., Kalimuthu, R., Ramakrishnan, D. Spectral pathways for exploration of secondary uranium: An investigation in the desertic tracts of Rajasthan and Gujarat, India. Advances in Space Research, 2019, 56, 1613-1626.

19. Bloise, A., Miriello, M. Multi-Analytical Approach for Identifying Asbestos Minerals in Situ. Geosciences, 2018, 8, 0; doi:10.3390/geosciences8040000

20. Booysen, R., Jackisch, R., Lorenz, S., Zimmermann, R., Kirsch, M., Nex, P.A.M., Gloaguen, R Detection of REEs with lightweight UAV-based hyperspectral imaging Scientific Reports, 2020, 10:17450; https://doi.org/10.1038/s41598-020-74422-0.

21. Booysen, R., Lorenz, S., Thiele, S. T., Fuchsloch, W. C., Marais, T., Nex, P. A. M., Gloaguen, R. Accurate hyperspectral imaging of mineralized outcrops: An example from lithium-bearing pegmatites at Uis, Namibia. Remote Sensing of Environment, 2022, 269, 112790; https://doi.org/10.1016/j.rse.2021.112790.

22. Bower, D. M., Yang, C.S.C., Hewagama, T., Nixon, C. A., Aslam, A., Whelley, P. L., Eigenbrode, J. L., Jin, F., Ruliffson, J., Kolasinski, J. R., Samuels, A. C. Spectroscopic characterization of samples from different environments in a Volcano-Glacial region in Iceland: Implications for in situ planetary exploration. Spectrochimica Acta Part A: Molecular and Biomolecular Spectroscopy, 2021, 263, 120205; https://doi.org/10.1016/j.saa.2021.120205 
23. Brandt, S.; Fassbender, M. L.; Klemd, R.; Macauley, C.; Felfer, P.; Haase, K. M. Cumulate olivine: A novel host for heavy rare earth element mineralization. Geology., 2020, doi:10.1130/g48417.1

24. Bhatt, C. R., Jain, C. J., Gouegue, C. L., McIntyre, D. L., and Singh, J. P. Determination of Rare Earth Elements in Geological Samples Using Laser-Induced Breakdown Spectroscopy (LIBS). Applied Spectroscopy, 2017, 1-8. DOI: $10.1177 / 0003702817734854$

25. Buckley, S. Geochemical analysis using laser-induced breakdown spectroscopy, Spectroscopy, 2021, 36, 10, 9-14.

26. Camara, C. G., Escobar, J. V., Hird, J. R., Putterman, S. J. Correlation between nanosecond x-ray flashes and stick-slip friction in peeling tape. Nature, 2008, 455, 1089-1092.

27. Cao, Y., Linnen, R., Good, D., Samson, I. Applications of the combined portable XRF-benchtop SEM methodology to PGE exploration. Ore Geology Reviews, 2018,101, 32-53. doi:10.1016/j.oregeorev.2018.07.0

28. Chakraborty, R, Kereszturi, , G. Durance, P. Pullanagari, R, Ashraf . S., Anderson, C. "Biogeochemical Exploration of Gold Mineralization and its Pathfinder Elements Using Hyperspectral Remote Sensing," IGARSS 2020 - 2020 IEEE International Geoscience and Remote Sensing Symposium, 2020, 5119-5122, doi: 10.1109/IGARSS39084.2020.9323737.

29. Connors, B., Somers, A., Day, D. Application of Handheld Laser-Induced Breakdown Spectroscopy (LIBS) to Geochemical Analysis. Applied Spectroscopy, 2016, 70(5), 810-815. doi:10.1177/0003702816638247

30. Cohen, N. E., Brooks, R. R., Reeves, R. D. Pathfinders in geochemical prospecting for uranium in New Zealand. Economic Geology,1969, 64(5), 519-525. doi:10.2113/gsecongeo.64.5.519

31. Crocombe, R. A. Portable Spectroscopy. Applied Spectroscopy, 2018, 72, 12, 1701-1751; DOI: 10.1177/0003702818809719

32. Day, D. Handheld Laser Induced Breakdown Spectroscopy (HHLIBS). Portable Spectroscopy and Spectrometry 1: Technologies and Instrumentation, first edition, Richard A. Crocombe, R. A., Leary, P. E and Kammrath, B. W (Eds), John Wiley \& Sons Ltd, 2021, 321-343.

33. Dhanada V S, George, S. D., Kartha, V. B., Chidangil, S., Unnikrishnan, V. K. Hybrid LIBS-Raman-LIF systems for multimodal spectroscopic applications: a topical review. Applied Spectroscopy Reviews, 2020, 1-30; https://doi.org/10.1080/05704928.2020.1800486

34. Dehaine, Q.; Tijsseling, L.T.; Rollinson, G.K.; Buxton, M.W.N.; Glass, H.J. Geometallurgical Characterisation with Portable FTIR: Application to Sediment-Hosted Cu-Co Ores. Minerals, 2022, 12, 15.https://doi.org/10.3390/min12010015

35. Dunlea, A. G., Murray, R. W., Tada, R., Alvarez-Zarikian, C. A., Anderson, C. H., Gilli, A., et al. Intercomparison of XRF core scanning results from seven labs and approaches to practical calibration. Geochemistry, Geophysics, Geosystems, 2020, 21, e2020GC009248. https://doi.org/10.1029/2020GC009248

36. Duée, C., Orberger, B., Maubec, N., Laperche, V., Capar, L. et al. Impact of heterogeneities and surface roughness on pXRF, pIR, XRD and Raman analyses: Challenges for on-line, real-time combined mineralogical and chemical analyses on drill cores and implication for "high speed" Ni-laterite exploration, Journal of Geochemical Exploration, 2018, 198, 1-17, https://doi.org/10.1016/j.gexplo.2018.12.010

37. Durance, P., Jowitt, S. M., Bush, K. An assessment of portable X-ray fluorescence spectroscopy in mineral exploration, Kurnalpi Terrane, Eastern Goldfields Super terrane, Western Australia. Applied Earth Science (Trans. Inst. Min. Metall. B), 2014, 123, 3, 150-163; DOI 10.1179/1743275814Y.0000000052

38. Fabre, C., Ourti, N. E., Mercadier, J., Fernandes, J. C., Dias, F., Perrotta, M., Koerting, F., Lima, A., Kaestner, F., Koellner, N., Linnen, R., Benn, D., Martins, T., Cauzid, J. Analyses of Li-Rich Minerals Using Handheld LIBS Tool. Data, $2021,6,68$. https://doi.org/10.3390/data6060068

39. Fuchs, M. C., Beyer, J., Lorenz, S., Sharma, S., Renno1, A. D., Heitmann, J., Gloaguen, R A spectral library for laser-induced fluorescence analysis as a tool for rare earth element identification. Earth Syst. Sci. Data, 2021, 13, 4465-4483; https://doi.org/10.5194/essd-13-4465-2021.

40. Gale, G.H. Vectoring volcanogenic massive sulphide deposits using rare earth elements and other pathfinder elements at the Ruttan mine, Manitoba (NTS 63B5); in Report of Activities 2003, Manitoba Industry, Trade and Mines, Manitoba Geological Survey, 2003, 54-73.

41. Gallhofer, D., Lottermoser, B. G. The influence of spectral interferences on critical element determination with portable xray fluorescence spectrometer (pXRF). Minerals, 2018. 8, 320. https://doi.org/10.3390/ min8080320.

42. Gonzalez-Fernandez, O., Rivero, L., Queralt, I., Viladevall, M. Distribution of metals in vadose zone of the alluvial plain in a mining creek inferred from geochemical, mineralogical and geophysical studies: The Beal Wadi Case (Cartagena-La Union Mining District, SE Spain). Water, Air, \& Soil Pollution, 2011, 221, 45-61. https://doi.org/10.1007/ s11270-011-0768-y.

43. Groppo, C., Rinaudo, c., Cairo, S., Gastaldi, D., Compagnoni. Micro-Raman spectroscopy for a quick and reliable identification of serpentine minerals from ultramafics. Eur. J. Mineral., 2006, 18, 319-329.

44. Hale, M. Pathfinder Applications of Arsenic, Antimony and Bismuth in Geochemical Exploration. Developments in Economic Geology, 1981, 307-323. doi:10.1016/b978-0-444-42012-1.50024-6

45. Hall, G. E. M., McClenaghan, M. B., Pagé, L. Application of portable XRF to the direct analysis of till samples from various deposit types in Canada. Geochemistry: Exploration, Environment, Analysis, 2015, 16(1), 62-84. doi:10.1144/geochem2015371

46. Hansford, G., Thomas, R. Handheld X-ray Diffraction for Remote, Field-Based Applications, Spectroscopy, 2015, 30, 7, 1421. 
47. Harder, I. M. K., Spry, P. G., McCombs, A. L. Zhang, H. Identifying pathfinder elements for gold in bulk-rock geochemical data from the Cripple Creek Au-Te deposit: a statistical approach. Geochemistry: Exploration, Environment, Analysis, 2021, 21 (1), geochem2020-048; https://doi.org/10.1144/geochem2020-048

48. Hark, R.R. Harmon, R.S. Geochemical Fingerprinting Using LIBS: in Laser Induced Breakdown Spectroscopy - Theory \& Applications (S. Musazzi and U. Perini, editors), Springer, 2014, 309-348.

49. Harmon, R. S., Lawley, C. J. M., Watts, J., Harraden, C. J., Somers, A. M., Hark, R. R. Laser-Induced Breakdown Spectroscopy-An Emerging Analytical Tool for Mineral Exploration; Minerals, 2019, 9, 718; doi:10.3390/min9120718

50. Harhira, A., Bouchard, P., Rifai, K., Haddad, J. E., Sabsabi, M., Blouin, A. Laflamme, M. Advanced laser-induced breakdown spectroscopy (LIBS) sensor for gold mining. The 56th Conference of Metallurgists COM, Canada, 2017, ISBN: 978-1926872-36-0.

51. Hattori K. H. Cameron E. M. Using the high mobility of palladium in surface media in exploration for platinum group element deposits: evidence from the Lac des Iles region, northwestern Ontario. Economic Geology, 2004, 99, 157-171.

52. Idris, N., Lahna, K., Ramli, M., Abidin, T. F., Budi, W. S., Suliyanti, M. M., Kurniawan, K. H., Tjia, M. O., Kagawa, K. Characteristics of laser induced breakdown investigated by a compact, nongated optical multichannel analyzer system and its potential application. Heliyon, 2020, 6, e05711;https://doi.org/10.1016/j.heliyon.2020.e05711

53. Johnsen, A. R., Thomsen, T. B., Thaarup, S. M. Test of vegetation-based surface exploration for detection of Arctic mineralisations: the deep buried Kangerluarsuk $\mathrm{Zn}-\mathrm{Pb}-\mathrm{Ag}$ anomaly. Journal of Geochemical Exploration, $2020,106665$. doi:10.1016/j.gexplo.2020.106665

54. Joyce, N. J. Alteration Mineralogy and Pathfinder Element Inventory in the Footprint of the Mcarthur River UnconformityRelated Uranium Deposit, Canada. A Master's thesis submitted to the Department of Geological Sciences and Geological Engineering, Queen's University, 2016, Kingston, Ontario, Canada

55. Kadel-Harder, I. M., Spry, P. G., McCombs, A. L., Zhang, H. Identifying pathfinder elements for gold in bulk-rock geochemical data from the Cripple Creek $\mathrm{Au}-\mathrm{Te}$ deposit: a statistical approach. Geochemistry: Exploration, Environment, Analysis, 2021, 21 (1): geochem2020-048. https://doi.org/10.1144/geochem2020-048

56. Kakavand, A., Adl-Zarrabi, B. Introduction of possible inspection methods for evaluating thermal aging status of existing pre-insulated district heating systems. Department of Civil and Environmental Engineering, Division of Building Technology, Chalmers University of Technology, Gothenburg, Sweden, 2015,1-29.

57. Kerrich, R., Wyman, D. A. Review of developments in trace-element fingerprinting of geodynamic settings and their implications for mineral exploration. Australian Journal of Earth Sciences, 1997, 44,4, 465-487. doi:10.1080/08120099708728327

58. Killeen, P. Gamma ray spectrometric methods in uranium exploration-Application and interpretation. Geophys. Geochem. Search Met. Ores 1979, 31, 163-230.

59. Kim, Y., Caumon, M. C., Barres, O., Sall, A. Cauzid, J. Identification and composition of carbonate minerals of the calcite structure by Raman and infrared spectroscopies using portable devices. Spectrochimica Acta Part A: Molecular and Biomolecular Spectroscopy, 2021, 261, 119980; https://doi.org/10.1016/j.saa.2021.119980

60. Korshunova, V.A., Charykova, M. V. Mobile Forms of Gold and Pathfinder Elements in Surface Sediments at the Novye Peski Gold Deposit and in the Piilola Prospecting Area (Karelia Region) Minerals, 2019, 9, 34; doi:10.3390/min9010034

61. Laperche, V.; Lemière, B. Possible Pitfalls in the Analysis of Minerals and Loose Materials by Portable XRF, and How to Overcome Them. Minerals 2021, 11,33. https://doi.org/10.3390/min11010033

62. Lemiere, B. A Review of pXRF (Field Portable X-ray Fluorescence) Applications for Applied Geochemistry. Journal of Geochemical Exploration, 2018, 188, 350-363, ff10.1016/j.gexplo.2018.02.006ff.ffhal-01740950f

63. Lemière, B., Uvarova, Y. A. New developments in field portable geochemical techniques and on-site technologies and their place in mineral exploration. Geochemistry: Exploration, Environment, Analysis, 2019, 20, 205-216, doi:10.1144/geochem2019-044

64. Levitan, D.M., Hammarstrom, J.M., Gunter, M.E., Ii, S., Robert, R., Chou, I-M., Piatak, N.M. Mineralogy of mine waste at the Vermont asbestos group mine, Belvidere Mountain, Vermont. American Mineralogist, 2009, 94, 1063-1066.

65. Layton-Matthews, D.; McClenaghan, M.B. Current Techniques and Applications of Mineral Chemistry to Mineral Exploration; Examples from Glaciated Terrain: A Review. Minerals, 2022, 12, 59. https://doi.org/10.3390/min12010059

66. Liancun, X., Zhizhong, Z., Chunxia, C., \& Yang, G. Mineral identification and geological mapping using near-infrared spectroscopy analysis. 2017 International Conference on Progress in Informatics and Computing (PIC), 2017, doi:10.1109/pic.2017.8359526

67. Lindagato, P., Li, Y., Yang, G., Duan, F. Wang, Z. Application of geostatistical analyst methods in discovering concealed gold and pathfinder elements as geochemical anomalies related to ore mineralization. Geologos, 2018, 24, 2, 95-109; doi: 10.2478/logos-2018-0010

68. Liu, C., Guo, J., Tian, Y., Zhang, C., Cheng, K., Ye W., Zheng, R. Development and Field Tests of a Deep-Sea Laser-Induced Breakdown Spectroscopy (LIBS) System for Solid Sample Analysis in Seawater. Sensors, 2020, 20, 7341; doi:10.3390/s20247341

69. Lundsgaard-Nielsen SM, Pors A, Banke SO, Henriksen J.E, Hepp DK, Weber A. Critical-depth Raman spectroscopy enables home- use non-invasive glucose monitoring. PLoS ONE, 2018, 13, 5, e0197134. https://doi.org/10.1371/journal. 
70. Maden, N. Akarya, E. Gamma ray spectrometry for recognition of hydrothermal alteration zones related to a low sulfidation epithermal gold mineralization (eastern Pontides, NE Türkiye). Journal of Applied Geophysics, 2015, 122, 74-85; https://doi.org/10.1016/j.jappgeo.2015.09.003

71. Makvandi, S.; Beaudoin, G.; McClenaghan, M.B.; Quirt, D.; Ledru, P. PCA of Fe-oxides MLA data as an advanced tool in provenance discrimination and indicator mineral exploration; case study from bedrock and till from the Kiggavik U deposits area (Nunavut, Canada). J. Geochem. Explor., 2019, 197, 199-211.

72. McClenaghan, M.B. Indicator mineral methods in mineral exploration. Geochemistry: Exploration, Environment, Analysis, 2005, 5, 233-245

73. McClenaghan, M.B., Parkhill, M.A., Pronk, A.G., Sinclair, W.D., Indicator mineral and till geochemical signatures of the Mount Pleasant W-MoBi and Sn-Zn-In deposits, New Brunswick, Canada, Journal of Geochemical Exploration, 2016, doi: 10.1016/j.gexplo.2016.10.00

74. McCay, A. T., Harley, T. L., Younger, P. L., Sanderson, D. C. W. Cresswell, A. J. Gamma-ray Spectrometry in Geothermal Exploration: State of the Art Techniques. Energies, 2014, 7, 4757-4780; doi:10.3390/en7084757energies

75. van der, M. F. Near-infrared laboratory spectroscopy of mineral chemistry: A review. International Journal of Applied Earth Observation and Geoinformation, 2018, 65, 71-78. doi:10.1016/j.jag.2017.10.004

76. Meima, J.A., Rammlmair, D. Investigation of compositional variations in chromitite ore with imaging Laser Induced Breakdown Spectroscopy and Spectral Angle Mapper classification algorithm. Chem. Geol., 2020, 532, 119376; https://doi.org/10.1016/j.chemgeo.2019.119376.

77. Meima, J. A., Rammlmair, D. Junge, M. The use of Laser Induced Breakdown Spectroscopy for the mineral chemistry of chromite, orthopyroxene and plagioclase from Merensky Reef and UG-2 chromitite, Bushveld Complex, South Africa. Chemical Geology, 2022, 589, 120686; https://doi.org/10.1016/j.chemgeo.2021.120686

78. Miller KA, Brigden K, Santillo D, Currie D, Johnston P., Thompson K. F. Challenging the Need for Deep Seabed Mining from the Perspective of Metal Demand, Biodiversity, Ecosystems Services, and Benefit Sharing. Front. Mar. Sci., 2021, 8:706161. doi: 10.3389/fmars.2021.706161

79. Milinovic, J., Barriga, F.J. Murton, B. J. Analysis of deep-ocean sediments from the TAG hydrothermal field (MAR, $26^{\circ}$ N): application of short-wave infrared reflectance (SWIR) spectra for offshore geochemical exploration. J Soils Sediments, 2020, 20, 3472-3486 https://doi.org/10.1007/s11368-020-02691-3

80. Milinovic, J.; Rodrigues, F.J.L.; Barriga, F.J.A.S.; Murton, B.J. Ocean-Floor Sediments as a Resource of Rare Earth Elements: An Overview of Recently Studied Sites. Minerals, 2021, 11, 142. https:// doi.org/10.3390/min11020142

81. Morgenstern, R., Turnbull, R. E., Hill, M. P., Durance, P.M.J. Rattenbury, M. S., Rare Earth Element Mineral Potential in New Zealand G N S Science Consultancy Report, 2018, 1-220

82. Moroz, T.N., Edwards, H. G. M. Zhmodik, S.M. Detection of carbonate, phosphate minerals and cyanobacteria in rock from the Tomtor deposit, Russia, by Raman spectroscopy. Spectrochimica Acta Part A: Molecular and Biomolecular Spectroscopy, 2021, 250, 119372; https://doi.org/10.1016/j.saa.2020.119372

83. Mukhopadhyay, P. Development and Characterization of Diode Pumped Solid State Lasers. Saarbrucken, Germany: LAP LAMBERT Academic Publishing GmbH \& Co. KG, 2011.

84. Nude, P. M., Asigri, J. M., Yidana, S. M., Arhin, E., Foli, G. Kutu. J. M. Identifying Pathfinder Elements for Gold in MultiElement Soil Geochemical Data from the Wa-Lawra Belt, Northwest Ghana: A Multivariate Statistical Approach. International Journal of Geosciences, 2012, 3, 62-70; http://dx.doi.org/10.4236/ijg.2012.31008

85. Nzulu, G., Eklund, P. Magnuson, M. Characterization and identification of Au pathfinder minerals from an artisanal mine site using X-ray diffraction. J. Mater. Sci., 2021, 56:7659-7669; https://doi.org/10.1007/s10853-020-05681-5

86. Nyga, R., Neu, W.,1993. Double-pulse technique for optical emission spectroscopy of ablation plasmas of samples in liquids. Opt. Lett. 18, 747-749.

87. Obhođaš, J., Sudac, D., Meric, I., Pettersen, H. E. S., Uroić, M., Nađ, K., Valković, V. In-situ measurements of rare earth elements in deep sea sediments using nuclear methods. Scientific Reports, 2018 8:4925 I DOI:10.1038/s41598-018-23148-1

88. Orlando, A.; Franceschini, F.; Muscas, C.; Pidkova, S.; Bartoli, M.; Rovere, M.; Tagliaferro, A. A Comprehensive Review on Raman Spectroscopy Applications. Chemosensors, 2021, 9, 262. https:// doi.org/10.3390/chemosensors9090262

89. Paradis, M.-C.M.; Doucet, F.R.; Rifai, K.; Özcan, L.Ç.; Azami, N.; Vidal, F. ECORE: A New Fast Automated Quantitative Mineral and Elemental Core Scanner. Minerals, 2021, 11, 859. https://doi.org/10.3390/min11080859

90. Paulen, R. C., Paradis, S., Plouffe, A and Smith, I. R. Base metal exploration using indicator minerals in glacial sediments, northwestern Alberta, Canada. Proceedings of the 24th IAGS, Fredericton, 2009, 557-560.

91. Plouffe, A. The glacial transport and physical partitioning of mercury and gold in till: Implications for mineral exploration with examples from central British Columbia, Canada. Geol. Soc. Lond. Spec. Publ., 2001, 185, 287-299.

92. Plimer, I. R., Elliott, S. M. The use of Rb/Sr ratios as a guide to mineralization. Journal of Geochemical Exploration, 1979, 12, 21-34. doi:10.1016/0375-6742(79)90060-8

93. Pochon, A., Desaulty, A. M., Bailly, L. Handheld Laser-Induced Breakdown Spectroscopy (LIBS) as a fast and easy method to trace gold. Journal of Analytical Atomic Spectrometry, 2020, 35, 254-264; doi:10.1039/c9ja00437h

94. Pöllmann, H.; König, U. Monitoring of Lithium Contents in Lithium Ores and Concentrate-Assessment Using X-ray Diffraction (XRD). Minerals, 2021, 11, 1058. https://doi.org/10.3390/min11101058 
95. Potts, P. J., Webb, P. C. X-ray fluorescence spectrometry. Journal of Gechemistry Exploration., 1992, 44, 251-296.

96. Porter, J. K.; McNaughton, N. J.; Evans, N. J.; McDonald, B. J. Rutile as a pathfinder for metals exploration. Ore Geology Reviews, 2020, 120, 103406. doi:10.1016/j.oregeorev.2020.1034

97. Rammelkamp, K., Gasnault, O., Forni, O., Bedford, C. C., Dehouck, E., Cousin, A., et al. Clustering supported classification of ChemCam data from Gale crater, Mars. Earth and Space Science, 2021, 8, e2021EA001903. https://doi.org/10.1029/2021EA001903

98. Rethfeldt, N.; Brinkmann, P.; Riebe, D.; Beitz, T.; Köllner, N.; Altenberger, U.; Löhmannsröben, H.-G. Detection of Rare Earth Elements in Minerals and Soils byLaser-Induced Breakdown Spectroscopy (LIBS) Using Interval PLS. Minerals, 2021, 11, 1379. https:// doi.org/10.3390/min11121379

99. Robertson, M. E. A and Feather, C. E. Determination of gold, platinum and uranium in South African ores by high-energy XRF spectrometry, X-Ray Spectrom., 2004, 33: 164-173

100. Rosa, R. D. L., Khodadadzadeh , M., Tusa, L., Kirsch, M., Gisbert, Tornos, F., Delgado, R. T.,Gloaguen, R. Mineral quantification at deposit scale using drill-core hyperspectral data :A case study in the Iberian Pyrite Belt. Ore Geology Reviews, 2021, 139, 104514; https://doi.org/10.1016/j.oregeorev.2021.104514

101. Rull, F., Veneranda, M., Manrique-Martinez, J. A., Sanz-Arranz, A., Saiz, J., Medina, J., ... Lopez-Reyes, G. Spectroscopic study of terrestrial analogues to support rover missions to Mars - A Raman-centred review. Analytica Chimica Acta, 2021,339003. doi:10.1016/j.aca.2021.339003

102. Salisbury, J.W.; Walter, L.S.; Vergo, N. Mid-InfraRed (2.1-25 um) Spectra of Minerals: First Edition, 1st ed.; United States Geological Survey: Reston, VI, USA, 1986.

103. Sarala, P. New advances in geochemical exploration in glaciated terrain - examplesfrom northern Finland. In: Lentz, D., Thorne, K.G. and Beal, K.-L. (eds.), Proceedings of the 24th International Applied Geochemistry Symposium. Fredericton, New Brunswick, Canada, June 1st-4th, 2009. Volume II. The Association of Applied Geochemistry, 585-587.

104. Sarala, P. Comparison of different portable XRF methods for determining till geochemistry. Geochemistry, Exploration, Environment, Analysis, 2016,16, 181-192.https://doi.org/10.1144/geochem2012-162

105. Sergeeva, A. V., Zhitova, E. S., Nuzhdaev, A. A., Zolotarev, A., A., Bocharov, V. N and Ismagilova, R. M. Infrared and Raman Spectroscopy of Ammoniovoltaite, (NH4)2Fe2+5Fe3+ 3Al(SO4)12(H2O)18 . Minerals, 2020, 10, 9, 781; https://doi.org/10.3390/min10090781

106. Shives, R.B.K. Using gamma ray spectrometry to fi nd rare metals. In: Simandl, G.J. and Neetz, M., (Eds.), Symposium on Strategic and Critical Materials Proceedings, November 13-14, 2015, Victoria, British Columbia. British Columbia Ministry of Energy and Mines, British Columbia Geological Survey Paper, 2015, 3,199-209.

107. Simandl, G.J., Fajber, R and Paradis, S. Portable X-ray fluorescence in the assessment of rare earth element enriched sedimentary phosphate deposits. Geochemistry: Exploration, Environment, Analysis, 2014, 14, 161-169; http://dx.doi.org/10.1144/geochem2012-180

108. Simpson, M.P.; Christie, A.B. Exploration of New Zealand mineral deposits and geothermal systems usjing X-ray diffraction (XRD) and reflectance spectrometry (SWIR): a comparison of techniques, GNS Science Report, 2016, 61. 45 p. doi:10.21420/G2NP4D

109. Somarin, A., Zhou, L and Steinhage, I. Application of handheld XRF on Ta-Nb-Sn-W ore: Factory calibration or user calibration? Geochemical Journal, 2021, 55, 3, 149-158.

110. Somarin. K and Steinhage, I. Use of field-portable XRF in exploration of PGE-enriched zones in the Pilanesberg PGE deposit, Bushveld Complex, South Africa. Geochemistry: Exploration, Environment, Analysis, 2021, 21, geochem2020-075, https://doi.org/10.1144/geochem2020-075

111. Somarin, A., Zhou, L and Steinhage, I. Application of handheld XRF on Ta-Nb-Sn-W ore: Factory calibration or user calibration? Geochemical Journal, 2021, 55, 149-158; doi:10.2343/geochemj.2.0624

112. Stuart, M.B.; McGonigle, A.J.S.; Davies, M.; Hobbs, M.J.; Boone, N.A.; Stanger, L.R.; Zhu, C.; Pering, T.D.; Willmott, J.R. Low-Cost Hyperspectral Imaging with a Smartphone. J. Imaging, 2021, 7, 136; https://doi.org/10.3390/jimaging7080136

113. Steiner, B. M. Tools and Workflows for Grassroots Li-Cs-Ta (LCT) Pegmatite Exploration. Minerals, 2019, 9, 499; doi:10.3390/min9080499

114. Takaya Y, Yasukawa K, Kawasaki T, Fujinaga K, Ohta J, Usui Y, Nakamura K, Kimura J-I, Chang Q, Hamada M, et al. The tremendous potential of deep-sea mud as a source of rare-earth elements. Scientific Reports, 2018, 8:5763. doi:10.1038/s41598-018-23948-5.

115. Trueman, D.L. and Cerny, P. Exploration for Rare-Element Granitic Pegmatites. In: Cerny, P., Ed., Granitic Pegmatites in Science and Industry: Mineralogical Association of Canada Short Course Handbook, 1982, 8, 463-494.

116. Thornton, B., Takahashi, T., Sato, T., Sakka, T., Tamura, A., Matsumoto, Nozaki, Ohki, T., Ohki, K. Development of a deepsea laser-induced breakdown spectrometer for in situ multi-element chemical analysis. Deep Sea Research, 2015, 95, 20-36.

117. van de Ven, M., Gazley, M., Sterk, R., Aldrich, S and Werner, E. Exploration for Lithium-Caesium-Tantalum (LCT) pegmatites in New Zealand. New Zealand Minerals Forum, Hamilton, 2020, 87-91.

118. Vitek, P., Jehlicka, J and Edwards, H. G. M. Practical Considerations for the Field Application of Miniaturized Portable Raman Instrumentation for the Identification of Minerals. Applied Spectroscopy, 2013, 67, 7, 767-778.

119. Walting, R.J., Scadding, C. J and May, C. D. Chemical fingerprinting of gold using laser ablation-inductively coupled plasma-mass spectrometry (LA-ICP-MS). Journal of the Royal Society of Western Australia, 2014, 97: 87-96. 
120. Wise, M.A.; Harmon, R.S.; Curry, A.; Jennings, M.; Grimac, Z.; Khashchevskaya, D. Handheld LIBS for Li Exploration: An Example from the Carolina Tin-Spodumene Belt, USA. Minerals, 2022, 12, 77. https:// doi.org/10.3390/min12010077

121. Xie, X.; Wang, X.; Zhang, Q.; Zhou, G.; Cheng, H.; Liu, D.; Cheng, Z.; Xu, S. Multi-scale geochemical mapping in China. Geochemistry: Exploration, Environment, Analysis, 2008, 8, 333-341

122. Yellepeddi, R., Thomas, R. New developments in wavelength dispersive XRF and XRD for the analysis of foodstuffs and pharmaceutical materials. Spectroscopy, 2006, 21, 9, 36-41. 